\title{
DOMESTICATING WILDERNESS: \\ HOW NATURE AND CULTURE CONVERGE IN THE MUSEUM SPACE
}

Thesis Submitted in Fulfillment of the Requirements for the Degree of Master of Arts

\section{LISA GOULET}

Program in Museum Studies

Graduate School of Arts and Science

New York University

April 2018 


\begin{abstract}
My thesis compares the Hall of North American Mammals at the American Museum of Natural History and High Line park. I argue that museums and other cultural institutions using museological methodologies seek to construct specific visual rhetorics and narratives in order to shape how visitors define, understand, and place themselves in relation to nature. Both spaces use a combination of artistic display techniques informed by a foundation of scientific knowledge to represent the results of major shifts in thought about how we define nature and respond to problematic human impacts from the eras prior to their construction. The Hall of North American Mammals uses diorama displays that most prominently feature iconic species of animals and majestic landscape paintings, following in a traditional style and appreciation for nature that emerged from specific artistic and scientific developments through the nineteenth century. Conversely, the High Line uses architecture and sculptural planting design to guide visitors along a predetermined series of vignettes that display not only the park itself but also contemporary art and the surrounding New York landscape, following an environmentally-minded ethic that emerged with the twentieth century environmental movement. Though both sites promote an aesthetic appreciation of nature that has origins in the visual culture established in the nineteenth century, the High Line attempts to contemporize this experience through the synthesis of nature and human activity while the Hall of North American Mammals rests more firmly in a dated experience of nature as an other, separated from the human realm.
\end{abstract}




\section{Table of Contents}

$\begin{array}{ll}\text { Introduction } & 1\end{array}$

Nineteenth century landscape painting: the visual culture of nature $\quad 2$

Museums: from private collections to public spaces 5

Case studies and road map 11

The Wilderness: Hall of North American Mammals $\quad 14$

Precedents: Carl Akeley and the Hall of African Mammals 15

Diorama creation in the early twentieth century 19

The diorama hall as an immersive experience $\quad 22$

Artistic inspiration: the Hudson River school and Frederic Edwin Church 32

Politicizing nature: support for the national parks 43

Conclusion $\quad 45$

The Garden: High Line $\quad 48$

Precedents: Central Park and the pastoral style $\quad 48$

History of the High Line $\quad 50$

Design of the park

National parks and popular conservation $\quad 59$

$\begin{array}{ll}\text { Conclusion } & 63\end{array}$

$\begin{array}{ll}\text { The Designed Environment } & 65\end{array}$

$\begin{array}{ll}\text { Authenticity through art and science } & 65\end{array}$

$\begin{array}{ll}\text { Audience and access } & 67\end{array}$

$\begin{array}{ll}\text { The problem with wilderness } & 68\end{array}$

$\begin{array}{ll}\text { Conclusion } & 74\end{array}$

$\begin{array}{ll}\text { Bibliography } & 77\end{array}$ 


\section{Introduction}

"The only thing we have to preserve nature with is culture; the only thing we have to preserve wildness with is domesticity."

- Wendell Berry ${ }^{1}$

If you walk down the road from New York University's Bobst Library, you will soon pass by an unassuming forested lot hiding in plain sight. Nestled between the yards surrounding tall, concrete high-rises and Houston Street's neverending automobile traffic sits a rectangle of ancient Manhattan, blanketed in trees, shrubs, grasses, and flowers that grew before the buildings and roads. Alan Sonfist's Time Landscape suggests a modern desire to return to, or mourning for the loss of, a time before European contact. New York's is one of a series of the artist's landscapes that, as art historian Eleanor Heartney describes, "offer an encapsulated glimpse of a long-vanished world, reminding us that where humanity once sought shelter from the savage wilderness of nature, today nature must be sheltered from humankind."2 To bring this landscape to life, Sonfist meticulously researched the historical botany and geology of the site before sculpting and seeding. In this regard, art brings the wild into the domestic and the natural into the cultural, examining the ways we understand nature not only through the representation of this landscape but also through scientific query.

How do museums and cultural institutions seek to construct nature? And specifically, how do these constructions shift in meaning over time? To answer this question, I explore the displays of two prominent New York City cultural institutions: the Hall of North American

\footnotetext{
${ }^{1}$ Wendell Berry, Home Economics (San Francisco: North Point, 1987) 138.

${ }^{2}$ Eleanor Heartney, "Art \& Nature and Technology: Remaking Land and Body," in Art \& Today (New York: Phaidon Press, 2008), 173.
} 
Mammals at the American Museum of Natural History and the High Line park in Manhattan's Chelsea neighbourhood.

For the purposes of this project, I am drawing from scholarship in a wide range of academic fields. My primary sources include the displays of my case studies themselves, official websites, annual reports and archival documents, and literature written by museum staff or published in collaboration with the museums. Along with theoretical writing in not only museum studies but also the histories of art and science, landscape architecture, and environmental philosophy, I hope to provide meaningful context and bring about new understanding of how each of these sites seek to put forth a unique definition of nature as defined by the ideals and values of significant eras preceding them.

Nineteenth century landscape painting: the visual culture of nature

Most associate the nineteenth century as a tumultuous time in art history through the momentous movements of the burgeoning European avant-garde. Just as painters like JMW Turner and Paul Cezanne were challenging the limits of the art academy, American painting grew out of and then diverged from the European artistic tradition in its own way. During this time, American landscape painters defined the role of landscape as an integral part of the country's national identity. Although the pastoral landscape and natural elements had previously been included in American art, "images of the land did not become a major source of interest to American fine art painters until the early 1800s. As political, religious, and cultural leaders 
struggled to formulate the character of their new nation, many began to turn to one obvious characteristic_-its vast, untamed wilderness." 3

This wilderness became the defining feature of postcolonial America and formed a dramatic backdrop through which artists could enact moralistic narratives. In the Christian culture of the nineteenth century, painters became spiritual leaders through their depiction of godly lands: "In painting the face of God in the landscape so that the less gifted might recognize and share in that benevolent spirituality, they were among the spiritual leaders of America's flock. ${ }^{4}$ Nature, in turn, became not only about the beautiful and picturesque, but also the "sublime." Previously associated with a dramatic visual style, in this time, the term had taken on additional religious connotations to include the presence of an all-powerful deity and nature was the perfect place to evoke such feelings. Similarly, the meaning of the term wilderness shifted from barren and unusable land to the untamed but treasured natural resource we think of today. In the midst of these sea changes coupled with the moralistic intentions of the painters themselves, "Each view of nature, then, carried with it not only an esthetic view, but a powerful self-image, a moral and social energy that could be translated into action. Many of these projections on [sic] nature augmented the American's sense of his own unique nature, his unique opportunity, and could indeed foster a sense of destiny."

One of the most prominent distinguishable features common to nineteenth century landscape painting is the 'magisterial gaze,' coined by historian Albert Boime. This 'gaze' in its simplest form is a viewpoint from a height, looking over a valley and dramatic vista, intended to

\footnotetext{
${ }^{3}$ Frances K. Pohl, Framing America: A Social History of American Art (New York: Thames and Hudson, 2012) 144.

${ }^{4}$ Barbara Novak, Nature and Culture (New York: Oxford University Press, 2006) 12.

${ }^{5}$ Novak, Nature and Culture, 6
} 
evoke feelings of awe from the viewer akin to the experience of the first European colonizers and distinct to American Romantic movement. As Tricia Cusack emphasizes, the pioneer identity grew to encapsulate the patriarchal figure of "entrepreneur-developer" during the nineteenth century. "Land, liberty, and property became the cornerstones of a dynamic masculine progress into the wilderness," were exemplified through presence of the magisterial gaze. ${ }^{6}$ Like characters in a story, viewers can easily insert themselves into the shoes of the brave explorer figure and experience pristine wilderness as it was before seemingly touched by humans. Furthermore, Boime discusses the Hudson River, Luminist, and Rocky Mountain schools to connect their common goals despite seemingly disparate painting styles. ${ }^{7}$ This phenomenon of the magisterial gaze, once recognizable, can and should be taken into consideration when discussing the Hall of North American Mammals at AMNH. In the museum space, visitors can safely encounter wild animals without experiencing the fear and danger of meeting potential predators and experience the grandiose vistas of the wilderness without leaving the city in which they are inhabiting, enacting an experience akin to the mythical "entrepreneur-developer" pioneer.

Politics of land use and preservation came into play through landscape painting as, ironically, the treasured American wilderness was rapidly being settled and developed for agriculture and industry. Although artists had previously ruminated over the struggle between technological progress and picturesque landscapes, "Those of the Romantic Era," as Heartney notes, much like other figures such as early conservationist George Perkins Marsh and AMNH taxidermist Carl Akeley, "went so far as to suggest that man is not the center of the universe, but

\footnotetext{
${ }^{6}$ Tricia Cusack, "The Chosen People: The Hudson River School and the Construction of American Identity," in Riverscapes and National Identities (Syracuse University Press, 2010) 22.

${ }^{7}$ Albert Boime, The Magisterial Gaze (Washington: Smithsonian Institution Press, 1991).
} 
rather a virus-like aberration that must be curtailed for the health of the planet." ${ }^{8}$ Additionally, "Such intense reverence for nature came only with the realization that nature could be lost. Given the indissoluble union of God and nature at this moment, the fate of both God and nature is obvious. A future mourning the loss of faith and consumed with ecological nostalgia was not far away." By midcentury, the influence of the American wilderness ideal was palpable. During the 1850s, artist-intellectuals began calling for preservation of the landscapes they held dear. For example, in one of the first issues of The Crayon art journal, painter Asher B. Durand wrote a call for landscape artists to turn their attention away from European subject matter and towards "the 'lone and tranquil' lakes embosomed in ancient forests, that abound in our wild districts, the unshorn mountains surrounding them with their richly textured covering, the ocean prairies of the West, and many other forms of Nature yet spared from the pollutions of civilization."10

\section{Museums: from private collections to public spaces}

The museum as a type of structure has origins in classical antiquity, as Greek and Roman societies employed stratified, organized places for displaying repositories of knowledge and symbols of national power to different types of citizens. Public museums in Britain including the formation of the Ashmolean and British Museum allowed more public access than in the past, but this access was still often limited and highly mediated by staff--in other words, not truly publicly accessible in the way we think of it today.

The nineteenth century saw the widespread emergence of the modern museum from its roots in private collections of curiosities as a site of authoritative knowledge for the benefit of the

\footnotetext{
${ }^{8}$ Heartney, “Art \& Nature," 168.

${ }^{9}$ Novak, Nature and Culture, 12.

${ }^{10}$ Asher B. Durand, “Letters on Landscape Painting," Letter II, The Crayon 1 (Jan. 17, 1855) 35.
} 
public. In "The Origins of the Public Museum," Jeffrey Abt "explore[s] the nascence of the public museum by investigating the individual trajectories of 'public' and 'museum' as they began to intertwine during classical antiquity and the Renaissance." ${ }^{11}$ The formation of the Musée Louvre as France's national art museum in the late 1700s ostensibly serves as the first example of a museum space truly melding the 'public' and 'museum.' American museums, including the Museum of Natural History, were established soon after in the Louvre's stead.

In contrast to the state-led establishment of the Louvre, public museums in America were largely established by wealthy private citizens. Those who profited from the burgeoning resource-extraction and peripheral industries "devoted fortunes to acquiring all kinds of specimens and objects with a special appetite for works of art, other precious objects, and rare books and manuscripts. Those who possessed the wealth to acquire great collections also possessed the civic influence and social connections with other like-minded leaders to found cultural institutions modeled on those of Europe." 12

Built on a premise that these private collections were being made available to the public as an act of goodwill by their private founders, American museums "reflected [the] shift in founding documents which identified them with civic virtues of public service, education and social stability." Parallel to developments around national identity present in nineteenth century landscape painting, museums during this time period became an instructional space to create an educated and cultured public, especially focusing on Christian social values even in the secular space. ${ }^{13}$ Ultimately, as John Tresch points out, much like the Louvre, the AMNH "follow[s] the

\footnotetext{
${ }^{11}$ Jeffrey Abt, "The Origins of the Public Museum," in A Companion to Museum Studies, ed. S. MacDonald (Malden, MA: Wiley-Blackwell, 2006), 115.

${ }^{12}$ Abt, "Origins of the Public Museum," 130.

${ }^{13}$ Abt, "Origins of the Public Museum," 132.
} 
universal survey museum's aims: a representative completeness, ordered by epochs, in a framework of triumphant nationalism." ${ }^{\prime 4}$ In the example of the Museum of Natural History's Hall of North American Mammals, it is thus fitting that art playing to the sublime, pristine wilderness popularized during this period would be displayed within its halls, and continue to hold symbolic power in the present day, leading museum employee and writer Stephen Quinn to boldly assert "the American Museum of Natural History could be considered the Louvre of diorama art." 15

Carol Duncan and Alan Wallach position the physical structures of museums in the same architectural and art historical class as "temples, churches, shrines and certain types of palaces" as spaces which communicate society's ideological beliefs and values akin to these other structures did in the past. ${ }^{16}$ In addition to communicating the importance of the institution to greater public society, museum architecture functions to organize visitors passing through because it "selects and arranges works of art within a sequence of spaces." Both the Museum of Natural History and High Line adhere to this sequencing of spaces, imposing a ceremonial/ritual structure that guides each visitor's experience through an ideological narrative "that casts [them] in the role of an ideal citizen, a member of an idealized 'public' and heir to an ideal, civilized past." ${ }^{17}$ Drawing from its roots as a royal gallery, the new public museum required a new organization of information meant not only to be conducive to the appreciation of its contents, but also to educate its viewer about the finer nuances of the history of the subject displayed.

\footnotetext{
${ }^{14}$ Carin Berkowitz and Bernard Lightman, eds., Science museums in Transition: Cultures of Display in Nineteenth-Century Britain and America, (Pittsburgh: University of Pittsburgh Press, 2017) 264.

${ }^{15}$ Stephen C. Quinn, Windows on Nature: The Great Habitat Dioramas of the American Museum of Natural History (New York: Harry N. Abrams, 2006), 12.

${ }^{16}$ Carol Duncan and Alan Wallach, "The Universal Survey Museum," in Art History, vol. 3 no. 4 (December 1980): 448-449.

${ }^{17}$ Duncan and Wallach, “The Universal Survey Museum,” 450-452.
} 
Thus, an architectural script "imposes the same underlying structure on everyone" through the physical forms the museum space takes. By following in this structure, the visitor participates in a ritual, which prompts the visitor "to enact and thereby to internalize the values and beliefs written into the architectural script." Whereas Duncan and Wallach describe "works of art that play the role of traditional ceremonial monuments," the 'work of art' is a mutable placeholder for many types of displays that span across museum genres. Both the Museum of Natural History and the High Line hold similar displays that take the place of works of art: respectively, the nature diorama and the naturalistic garden vignette. ${ }^{18}$ Though art museums are more readily compared to religious institutions, the relationship between science museum and religion is more tenuous. The traditionally-designed science museum, such as the AMNH, is perhaps a vestige of belief in natural theology, a field which made a sharp distinction between natural and human innovation, and was a popular opposition to the Darwinist evolutionary point of view during the nineteenth century. Under this belief, natural theology defined the purpose of a natural history museum to be "to show the greatness of God in the variety of nature." originally had no place in the natural history museum, as it was intended to house collections of naturally-created objects. The separation between departments of study relating to humans and nature in the plans of natural history museums is evidence of a continued divide. However, a closer connection to the art museum resides in the practice of looking that are encouraged in both art and science museums. Just as visitors in art museums are guided to pay reverent attention to objects through a dissections of their symbolic details to foster an understanding of the larger

\footnotetext{
${ }^{18}$ Duncan and Wallach, "The Universal Survey Museum," 450.

${ }^{19}$ Carla Yanni, "Divine Display or Secular Science," in Journal of the Society of Architectural Historians vol. 55, no. 3 (September 1996) 276.
} 
piece's greater purpose of meaning, visitors in science museums are similarly encouraged to partake in a ritual of systematic looking that has more literal ramifications.

As public museums emerged in the eighteenth and nineteenth centuries, they were predominantly "private collections opened to the public, and, as long as that was made quite clear, there was, as mentioned earlier, no real problem. The trouble began with the introduction of a new idea: the democratic museum. ${ }^{, 20}$ Duncan Cameron argues that these public museums were created as "temples within which they enshrined those things they held to be significant and valuable." ${ }^{21}$ Museums in the twentieth century had changed in social function, but still held value: "reference here to the reform of museums does not mean plans to convert them into social clubs or funfairs but reform to make them better and more effective museums in the sense of the museum as a temple. The initial step will be to reestablish the museum's role or, if you wish, its social function."

Globalization in the twentieth century brought to light the need to rethink museum interpretation methods to counter the hegemony of the bourgeois and aristocratic culture, Cameron states "by failing to provide meaningful interpretation of the collections, museums are, by that omission, guilty of misrepresentation, distortion of fact, and the encouragement of attitudes toward cultures other than our own that are dangerous and destructive in what [Marshall] McLuhan has called today's 'global village.'",22

In the context of the twentieth century, the imperial structure of the public museums like the Louvre were thus viewed as oppressive. According to Cameron, the reform he describes must come in the form of reestablishing the museum as a forum space to be truly democratic. In a

\footnotetext{
${ }^{20}$ Duncan F. Cameron, "The Museum, a Temple or the Forum,” in Curator, vol. 14, no. 1 (March 1971 ), 65.

${ }^{21}$ Cameron, "Temple or Forum," 66

${ }^{22}$ Cameron, "Temple or Forum," 67.
} 
larger sense, the need for experimentation and disruption is particularly apparent in the arts and the museum can function as a space to fill this need, akin to the academic structure that funds scientific exploration. "The artist or scholar who criticizes our society and offends our sensitivities or our values is, in effect, regarded as an enemy of society even before we have allowed time for his work or his statements to be judges and considered." ${ }^{23}$ However, a crisis occurs when museums attempt to become both the temple and the forum. The precipice we then land on is the conundrum of which public to serve; "society will no longer tolerate institutions that either in fact or appearance serve a minority audience of the elite."24

${ }^{23}$ Cameron, "Temple or Forum," 69.

${ }^{24}$ Cameron, "Temple or Forum," 72. 


\title{
Case studies and road map
}

The seeds of this project were sown the first time I visited the Museum of Natural History's Hall of North American Mammals. Awestruck by the reverent atmosphere of the hall, I was immediately captivated not by the lifelike creatures housed behind the glass, but by the incredibly detailed painted landscapes they sat in front of. Something in the back of my mind connected these paintings to a time deep in the past. Through an examination of its diorama displays, I posit that the Hall is most effectively 'read' contextually using the web of ideas, values, practices, techniques, belief and knowledge systems that emerged during the nineteenth century as they informed a basis of knowledge that was foundational to its construction.

Open, airy, and bustling, the High Line exists in almost diametric opposition to the Hall within the Museum of Natural History. The High Line has long been a favourite space of mine, but I had never considered its museological qualities until revisiting nearly a year into my degree. In “America in Ruins,” Thomas Patin argues

\begin{abstract}
that national parks are essentially museological institutions, not because they preserve and conserve, but because they employ many of the techniques of display, exhibition, and presentation that have been used by museums to regulate the bodies and organize the vision of visitors. Such a strategy is essentially visual and rhetorical and produces a "vignette of America" that insinuates the institution of the museum into park spaces, produces specific understandings of the cultural and natural world, and furthers specific ideas of America's cultural heritage. ${ }^{25}$
\end{abstract}

Extending this idea beyond national parks, I propose that the High Line fits into Patin's definition of a museological institution and provides a worthy counterpoint to the longstanding Natural History Museum through an understanding of its conception as it is grounded in monumental developments in thought that emerged in the late twentieth century. Both of these

\footnotetext{
${ }^{25}$ Thomas Patin, "America in Ruins: Parks, Poetics, and Politics," in Observation Points: The Visual Poetics of National Parks (University of Minnesota Press, 2012), 270.
} 
museological sites have intentionally crafted dramatically different experiences that visually display the landscape with a specific symbolic weight to evoke specific emotional responses as a method of shaping how visitors define, understand, and place themselves in relation to nature. In essence, each space communicates a version of nature that is analogous to the time period preceding its creation and thus, continues to extend that version past its temporal life in the public imagination and exists contemporaneously amongst other crafted versions that persist to this day.

In this paper, I give you a glimpse at the museum's place amongst the history of these vast, interwoven fields of thought. Chapter 1 provides an overview of my first case study, The Hall of North American Mammals at the American Museum of Natural History. I will discuss the historical context in which the hall was conceived and constructed from during the Golden Era of museum diorama displays, and the rhetorical devices used to create a version of nature evident in the experience of visiting the hall through an analysis of nineteenth century American landscape painting and concurrent conservation movements, such as the establishment of the national parks.

Moving forward, Chapter 2 will discuss the history of my second case study, the High Line park. Situating it within the history of site-specific cultural form in the twentieth century, including garden spaces and national parks, will provide my framework to understand this reclaimed urban green space. Having followed a loose structure from the nineteenth to the twentieth centuries, Chapter 3 will cover the nuances of how these sites can be interpreted in the present day amongst these shifting definitions of nature and environmental ethics. What tensions arise when experiencing the timeless and unchanging dioramas of the Hall of North American 
Mammals alongside the swiftly evolving High Line, and what information can we glean from both of these sites out of time? 


\section{The Wilderness: Hall of North American Mammals}

"Time has stopped. Birds soar in suspended animation. Animals gaze in perpetual fixed attention. Clouds hover motionless in azure blue skies. Behind the glass, all of nature is locked in an instant of time for our close examination and study."

Deep inside the Museum of Natural History through a grand set of open doors lies a vast, darkened hall. As per the 1956 General Guide, "The Hall of North American Mammals is approached from the Hall of New York State Mammal exhibits, Roosevelt Building first floor. It was opened to the public on April 8, 1942. A few of the groups are still under construction."27 On a quiet day, footsteps echo through the main chamber as visitors shuffle from one radiating chapel to the next, taking in the vibrant, glittering wonders behind glass. The din of the city around them is silenced by the impenetrable walls of the sprawling stone building, allowing for time and space to slow down to a crawl. Sitting at the apse at the end of the hall, two Alaska brown bears watch over their flock as they gaze into the spectacular panoramic aisle displays, a dramatic battle between two Alaskan moose in the muskeg mud and a herd of bison lumbering across a wide plain (see Figure 1).

The bears stand in front of a sweeping mountain range awash in a fog of lilac as distant clouds descend from the peaks like gatekeepers to an impossible land, simultaneously remote yet within arm's reach. Around each corner lies a series of lesser deities: mountain lions, hares, caribou, wolves. Each window holds an entire world for its token species and their ideal habitat, everything they could ever need to live out their immortality in peace. Humans may come and go to worship at the altar, but they are only passing through. This is the cathedral of the animals.

\footnotetext{
${ }^{26}$ Stephen C. Quinn, Windows on Nature: The Great Habitat Dioramas of the American Museum of Natural History (New York: Harry N. Abrams, 2006), 8.

${ }^{27}$ American Museum of Natural History, General Guide (New York: Man and Nature Publications, 1956$), 135$.
} 


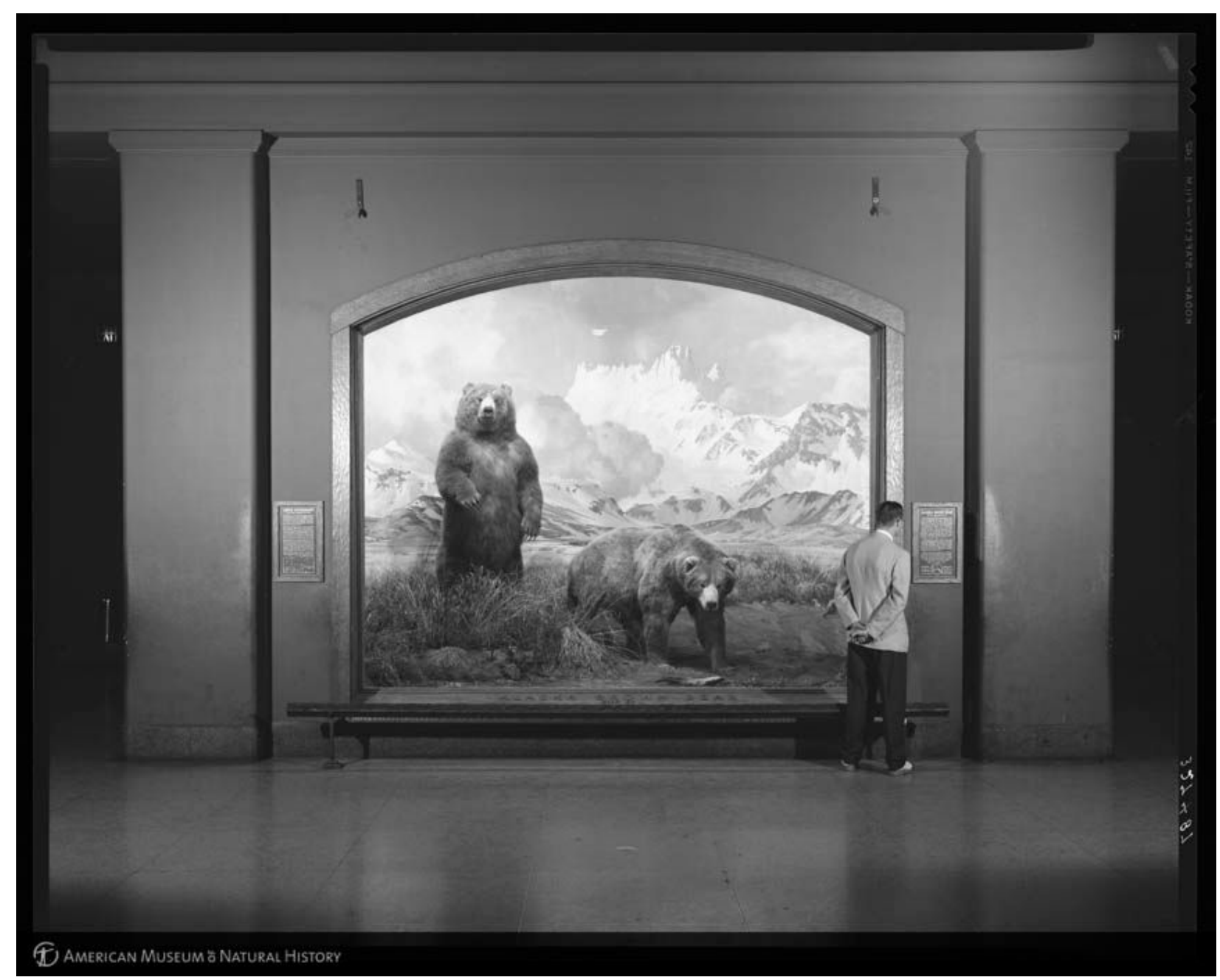

Figure 1. Alaska Brown Bear Group, North American Mammal Hall, 1960. Photograph by Alex J. Rota. Research Library | Digital Special Collections, The American Museum of Natural History.

Precedents: Carl Akeley and the Hall of African Mammals

It is helpful to first understand this site in the context of its famous predecessor, the Hall of African Mammals and its principal ideator Carl Akeley. Akeley is a contested figure in the history of the Museum of Natural History. He is celebrated extensively in the museum space as the originator of the African Mammal Hall — the subject which captivated him for most of his 
adult life. Although glorified by the museum itself in didactic labels and museum publications, scholars like Donna Haraway have problematized the actions he took in the name of conservation, most notably an approach to species conservation that was paradoxically tied to hunting for sport alongside wealthy museum donors.

Born in 1864, the same year George Perkins Marsh published Man and Nature, Akeley grew up during the establishment of the national parks and subsequent emergence of the early conservation movement. He developed an interest in taxidermy as a teenager, which became the way he expressed his love for nature and animals. As Haraway points out, "From the beginning Akeley's life had a single focus: the capturing and representation of the nature he saw." ${ }^{28} \mathrm{He}$ began his professional taxidermic career at Ward's Natural Science Establishment, an operation that provided scientific materials and specimens primarily to educational centres.

At Ward's “Akeley would spend four years and form a friendship pregnant with consequences for the nascent science of ecology as it came to be practiced in museum exhibition. ${ }^{29}$ Akeley's interest in the practical techniques of taxidermy grew here, driving him to become unhappy at Ward's, where taxidermy was a formulaic process. His keen interest in nature, coupled with this urge to hone his craft outside the bounds of the company led to his friendship with naturalist William Morton Wheeler. In 1885, Wheeler became a curator at the Milwaukee Museum of Natural History and brought the ambitious Akeley with him. Haraway describes, "Akeley opened up his business shop on the Wheeler family property, and he and the naturalist spent long hours discussing natural history, finding themselves in agreement both about museum display and about the character of nature. The most important credo for them was

\footnotetext{
28 Donna Haraway, “Teddy Bear Patriarchy: Taxidermy in the Garden of Eden, New York City." Social Text vol. 11(1984-1985): 30.

${ }^{29}$ Haraway, "Teddy Bear Patriarchy,” 30.
} 
the need to develop scientific knowledge of the whole animal in the whole group in nature." ${ }^{30}$ At the Milwaukee museum, Wheeler gave Akeley the freedom to pursue the art of taxidermy as he saw fit. Akeley began to attempt increasingly complicated taxidermy structures, mounting animals in groups and in situ with elements of the environments they inhabited. His first (and the first ever) diorama was created in 1889: a group of muskrats in a marsh, which are still on display to this day. ${ }^{31}$

In describing the innovation of the muskrat arrangement, historian John Tresch writes, "This discovery of the habitat diorama's trajectory is a specific case of a more general point. Museums show visitors that they, like Akeley's muskrats behind glass, are part of a larger ecology, that there are connections between lives lived locally and much wider and longer patterns of development." ${ }^{32}$ In 1896, Akeley went on his first expedition to source specimens for a new collection. It would be the first of five he would take in his lifetime, "each escalating his sense of the purity of the continent's vanishing wild life [sic] and the conviction that the meaning of his life was its preservation through transforming taxidermy into an art." ${ }^{33}$ Akeley donated mounted animals and photographs of his work to AMNH from Chicago's Field Museum and embarked on a major collecting expedition before moving permanently to the AMNH in $1913 .^{34,}$ ${ }^{35}$ At the Museum of Natural History Akeley would finally be able to realize his dream of creating a large African mammal collection. He believed that, as the birthplace of the human

\footnotetext{
${ }^{30}$ Haraway, "Teddy Bear Patriarchy," 31.

${ }^{31}$ Quinn, Windows on Nature, 15.

${ }^{32}$ Carin Berkowitz and Bernard Lightman, eds., Science museums in Transition: Cultures of Display in Nineteenth-Century Britain and America, (Pittsburgh: University of Pittsburgh Press, 2017) 262.

${ }^{33}$ Haraway, "Teddy Bear Patriarchy," 32.

${ }^{34}$ American Museum of Natural History, Annual Report (New York: American Museum of Natural History, 1894, 1903, 1909, 1910).

${ }^{35}$ American Museum of Natural History, Annual Report (New York: American Museum of Natural History, 1913) 27.
} 
species, preservation of African wilderness areas were top priority in the efforts of the early conservation movement to limit the destruction of Western industrialization. An entire hall dedicated to the unique large mammal species of the continent would be a moving and convincing display for the American public to support these efforts. Akeley was just one figure in a large group of scientists and wealthy sportsmen to embark on the challenge of creating the African mammal hall, as noted in the 1911 Annual Report:

Since 1907 the Museum has been carrying on very active exploration in Africa to secure the fast- vanishing forms of that continent before it becomes too late. All together $\$ 55$, ooo have been contributed by Trustees and friends for this purpose, the chief expeditions being:

The Tjäder Expedition, supported by Mr. Samuel Thorne.

The Fayûm Expedition, supported by Mr. Jesup and Professor Osborn.

The Congo Expedition, under Messrs. Lang and Chapin, supported by a group of the Trustees, together with a generous contribution from the Belgian Government.

The Elephant Group Expedition, under Mr. Carl E. Akeley, supported by several Trustees. ${ }^{36}$

Both Akeley and the museum, recognizing "the rapidity with which not only animals, but races of mankind with their beliefs and customs, are being swept out of existence by what we are pleased to call the march of civilization," embarked on numerous expeditions to Africa to secure plants and animal specimens for their collection before they vanished into extinction. ${ }^{37}$

Finally, the Akeley Hall of African Mammals was opened ten years after Akeley's death in 1936, with construction continuing into the $1950 \mathrm{~s} .{ }^{38}$ His crowning achievement, the stuffed silverback gorilla sits in a corner amongst a host of other African species: lions, giraffes, rhinoceros, ostriches, zebras, and a group of magnificent elephants. The elephant pack dominates the middle of a dimly lit room on a long plinth, as if they're about to parade off through the rest

\footnotetext{
${ }^{36}$ American Museum of Natural History, Annual Report (New York: American Museum of Natural History, 1911) 25.

${ }^{37}$ American Museum of Natural History, Annual Report.

${ }^{38}$ Quinn, Windows on Nature, 166.
} 
of the museum. The animals chosen for the hall are categorically "charismatic megafauna," the species of animals that attract the most positive public attention by virtue of their perceived attributes: cute and cuddly or large and majestic. ${ }^{39}$ The atmosphere is similar to the Hall of North American Mammals in that it is dimly lit, quiet, and reverent. The landscapes within this hall are not as pointedly majestic as the Hall of North American Mammals; rather, they serve as introductory invitations to linger inside and glimpse into foreign, and what would have been fairly unrecognizable, types of land. At present day, the hall looks old and faded, like a crumbling family photograph. Landscapes are rendered with quintessentially realistic scenery and dreamy pastel colours. Despite this, Akeley's visions and goals for the Hall of African Mammals as a display space in support of a wilderness conservation agenda set a precedent for the Hall of North American Mammals, that even after his death, are a product of his legacy in the museum.

\section{Diorama creation in the early twentieth century}

In the years following Akeley's death, the museum carried out more and more spectacular diorama hall projects in his stead. In Windows on Nature, the museum's most recent book dedicated entirely to their diorama halls, author and then-senior project manager in the museum's exhibitions department Stephen Quinn argues the "golden years" of the American natural history diorama display occurred from the 1920 s to early $1950 \mathrm{~s} .{ }^{40}$ This is perhaps better applied specifically to the AMNH, as Rader and Cain contend that the natural history diorama

\footnotetext{
${ }^{39}$ Though they receive a disproportionate amount of attention in conservation initiatives, these species are rarely the most ecologically important or productive members of the ecosystems they occupy. James P. Lester, editor, Environmental Politics and Policy: Theories and Evidence (Macmillan International Higher Education, 1992$) 216$. ${ }^{40}$ Quinn, Windows on Nature, 18-19.
} 
genre proliferated in American natural history museums between 1910 and the early 1930s,

creating a surge of popularity among the general public that lasted through to the postwar era. ${ }^{41,42}$ "In line with evolutionary notions crystallizing within nineteenth century biology," John Tresch suggests, "these dioramas conveyed a dynamic and relational understanding of both species and individuals, showing organisms as part of habitats formed by specific vegetative, geological, and meteorological features. ${ }^{\prime 3}$ The construction of the Hall of African Mammals sat squarely in the middle of this diorama boom along with many other halls. During this time period denoted by Quinn, the museum also opened the Hall of Pacific Bird Life, the Hall of Ocean Life, the Theodore Roosevelt Memorial, Birds of the World, the Hall of Asian Mammals, and the original Hall of North American Mammals.

The presence of diorama halls was exemplary of both the successes and failures of museums during this time. They were popular among the public, were considered very accessible, and provided curators the opportunity to conduct further field work. They were also horribly expensive and required the allocation of vast amounts of time and skilled labour towards their construction. ${ }^{44}$ By the 1930 s, diorama creators had realized the fatal flaw in their permanent displays: the static nature of the meticulously prepared diorama didn't allow new science to be easily integrated into it, and doing so required inelegant didactic material, which broke the magical atmosphere of the immersive experience that was the at the crux of its function.

\footnotetext{
${ }^{41}$ Karen A. Rader and Victoria E.M. Cain, Life on Display: Revolutionizing U.S Museums of Science and Natural History in the Twentieth Century (Chicago: The University of Chicago Press, 2014) 51.

${ }^{42}$ Extensive historical research on the proliferation of habitat diorama displays in natural history museums has been written in Karen A. Rader and Victoria E.M. Cain, Life on Display: Revolutionizing U.S Museums of Science and Natural History in the Twentieth Century (Chicago: The University of Chicago Press, 2014), and Karen Wonders, Habitat Dioramas: Illusions of Wilderness in Museums of Natural History (Uppsala: Allan Ellenius, 1993).

${ }^{43}$ Carin Berkowitz and Bernard Lightman, eds., Science museums in Transition: Cultures of Display in Nineteenth-Century Britain and America, (Pittsburgh: University of Pittsburgh Press, 2017) 265.

${ }^{44}$ Rader and Cain, Life on Display, 53.
} 
However, diorama and other similar mounted specimen displays continued to dominate museum halls through the Depression as administrators relied on them in lieu of updated galleries. Additionally, wealthy patrons who funded and often participated in the hunting expeditions required to collect specimens continued to donate money to their construction, keeping the tradition afloat. ${ }^{45}$

Owing to this proliferation of diorama halls in the early twentieth century was the growing realization that majestic, pristine wilderness, as it had been defined and cemented into the public consciousness in the nineteenth century, was disappearing. The practice of mounting and stuffing endangered animals for public education was seen as a method of preserving their existence for posterity as well as teaching audiences about the interconnected relationships between the different plants and animals of these environments. Rader and Cain make note that "a growing acceptance by scientists that nothing in nature is of isolated origin but rather is the product of complex interrelationships also fostered the diorama approach, which featured entire habitats rather than collections of individual specimens. ${ }^{{ }^{46}}$ Dioramas not only illustrated important relationships between the animals they depicted and their environments, but also their emotional appeal, which led many scientists and curators to believe that they could prompt public interest in wildlife conservation. Halls were designed with the intent of creating a completely immersive experience akin to travelling to new places for the first time, eliciting responses of wonder and awe at the beautiful landscape. For this reason, scientists argued that "birds and animals in their habitats aroused far more sympathy from viewers than synoptic

\footnotetext{
${ }^{45}$ Rader and Cain, Life on Display, 111.

${ }^{46}$ Rader and Cain, Life on Display, 15.
} 
displays ... and that sympathy led museumgoers to reflect on what they could do to preserve such creatures. ${ }^{247}$

Diorama displays continued to dominate the natural history museum space into the postwar years. Funding for scientific research blossomed, swinging the pendulum of their priorities away from educational and public programming once more. ${ }^{48}$ As Quinn describes, inside the hall "all of the talent, methods, and techniques developed and learned over the golden Akeley years [are] brought to perfection," and "its dioramas are considered to be the finest in the world." ${ }^{49}$ The construction process was so intensive that when the hall was first opened in 1942 only ten of its twenty-nine planned dioramas were open to the public. The remaining nineteen dioramas were completed by the hall's final dedication in 1954. Later, the secondary Small Mammal Corridor was opened in 1963. As it was built on the very tail end of this prolific time period, the Hall of North American Mammals was and continues to be the museum's ultimate habitat diorama hall.

\section{The diorama hall as an immersive experience}

Aside from being far from complete, when it was first opened the Hall of North American Mammals contained no didactic labels in the gallery. No text or graphics cluttered the environment of the hall, no subtle lighting to interrupt the visitor's communion with each glowing diorama scene. In a way that mimicked birdwatching out in the field, visitors learned about the complex relationships between the animals in the dioramas and their habitat through guidebooks. A.B. Meyer notes in a 1905 evaluation of major American museums that the

\footnotetext{
${ }^{47}$ Rader and Cain, Life on Display, 55.

${ }^{48}$ Rader and Cain, Life on Display, 139.

${ }^{49}$ Quinn, Windows on Nature, 19.
} 
American Museum of Natural History was at the forefront of educating its visitorship through printed media, publishing guides to the major collections as well as a quarterly museum journal and standalone pamphlets on topics extending past the museum's walls, such as "The Butterflies of New York and Vicinity" and "The North American Ruminant." ${ }^{\text {0 }}$ These publications were an easily accessible medium in terms of both economical and educational barriers. They were available to the public for a low price and full of illustrations with short descriptions of objects of interest rather than overly academic explanations. The reasons for constructing the dioramas of the Hall of North American Mammals were twofold: first, to underscore and teach the trends in emerging research interests in science at the time that prioritized understanding large systems of relationships over the inner-workings of individual specimens, and second, to evoke emotional appeal and gain support for the conservation movement. The experience of an immersive and reverent spectacle therefore lent itself perfectly to carry out these aims and was strengthened by this method of education that involved exploring the diorama hall with a handheld field guide rather than the use of didactic labels.

The immersive experience, as defined by film scholar Alison Griffiths in her book Shivers Down Your Spine, is a ritualistic spectatorial experience that was first brought into existence and codified in the Middle Ages by cathedrals and then solidified in popular visual culture by nineteenth century panoramas. These two precedents "established specific protocols for viewing immersive spectacle," and lead the way for the habitat diorama to emerge as a compelling form of immersive experience. ${ }^{51}$

\footnotetext{
${ }^{50}$ A.B. Meyer, "Studies of the Museums and Kindred Institutions of New York City, Albany, Buffalo, and Chicago, with Notes on Some European Institutions," in Report of the United States National Museum for 1903, (Washington: Government Printing Office, 1905) 327.

${ }^{51}$ Alison Griffiths, Shivers Down Your Spine: Cinema, Museums, and the Immersive View (New York: Columbia University Press, 2008) 5.
} 
Cathedrals establish the quintessential immersive experience by employing themes of "spectatorship, immersion, the reenactment, virtual travel, visual excess, mimesis, the uncanny, and death" through soaring architecture that predetermines a reaction of wonder and awe from its visitors, and the content of the visual iconography displayed within its space as a dualistic performative and immersive spectacle.$^{52}$ Drawing from Abraham Maslow's theory of "peak-experience," spectatorship in these spaces (originally applied by Maslow to cathedral, but here extended to include panoramas and habitat dioramas) is an act of "copresence" that gives people the feeling that they are in a more intimate relationship with their surroundings. This relationship in these spaces creates a peak-experience, evoking emotions of "wonder, awe, reverence, humility, surrender, and even worship before the greatness of the experience."${ }^{953}$ Under these dynamics, the structure of the cathedral is powerful enough to "transport worldly spectators into a transcendent realm. ${ }^{, 54}$ Cathedrals were among the first spaces to generate "a locus for a sense-altering experience" and also "created the conditions of possibility and deep-seated desire for an immersive engagement with illusionistic representational forms" that would inspire the creation of the panorama and the diorama. ${ }^{55}$

The cathedral most readily lends itself as inspiration for the habitat diorama hall through both the use of a cathedral-like floor plan and creation of a transcendent atmosphere. Contributing to the atmosphere of the space is the similar floor plan, containing the cruciform structure and key elements such as a nave, aisles, a transept, and an ambulatory (see Figure 2).

\footnotetext{
${ }^{52}$ Griffiths, Shivers Down Your Spine, ??.

${ }^{53}$ Abraham H. Maslow, Religions, Values, and Peak-Experiences (New York: Penguin/Arkana, 1994$) 65$.

${ }^{54}$ Griffiths, Shivers Down Your Spine, 36.

${ }^{55}$ Griffiths, Shivers Down Your Spine, 36.
} 
Both are dark, reverent spaces, lit only through wide, colourful windows. Like the stained glass scenes that adorn the walls of a cathedral, the scenes within the diorama hall are rendered in bright jewel-tones, giving almost divine qualities to the places they depict. Haraway makes additional connections between the diorama hall and the cathedral, stating that "a diorama is eminently a story, a part of natural history. The story is told in the pages of nature, read by the naked eye. The animals in the habitat groups ... are actors in a morality play on the stage of nature, and the eye is the critical organ." ${ }^{56}$ Where biblical narratives adorn the walls of a cathedral, the animals in each diorama reenact a scene from their past lives, hinted at in early museum guidebooks. In the Alaskan Moose diorama, "two great bulls [are] locked in a struggle for mastery over a cow, which appears unconcerned over the outcome," ${ }^{57}$ while in the Dall Sheep's habitat, "handsome rams are resting far above the timber line on a mountain in Alaska, with the golden glow of the 'midnight sun' striking the white peak of Mount McKinley in the background." 58

\footnotetext{
${ }^{56}$ Haraway, Teddy Bear Patriarchy, 24.

${ }^{57}$ American Museum of Natural History, Annual Report (New York: American Museum of Natural History, 1954) 135.

${ }^{58}$ American Museum of Natural History, Annual Report, 135.
} 


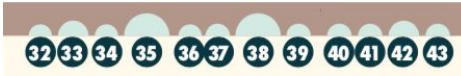

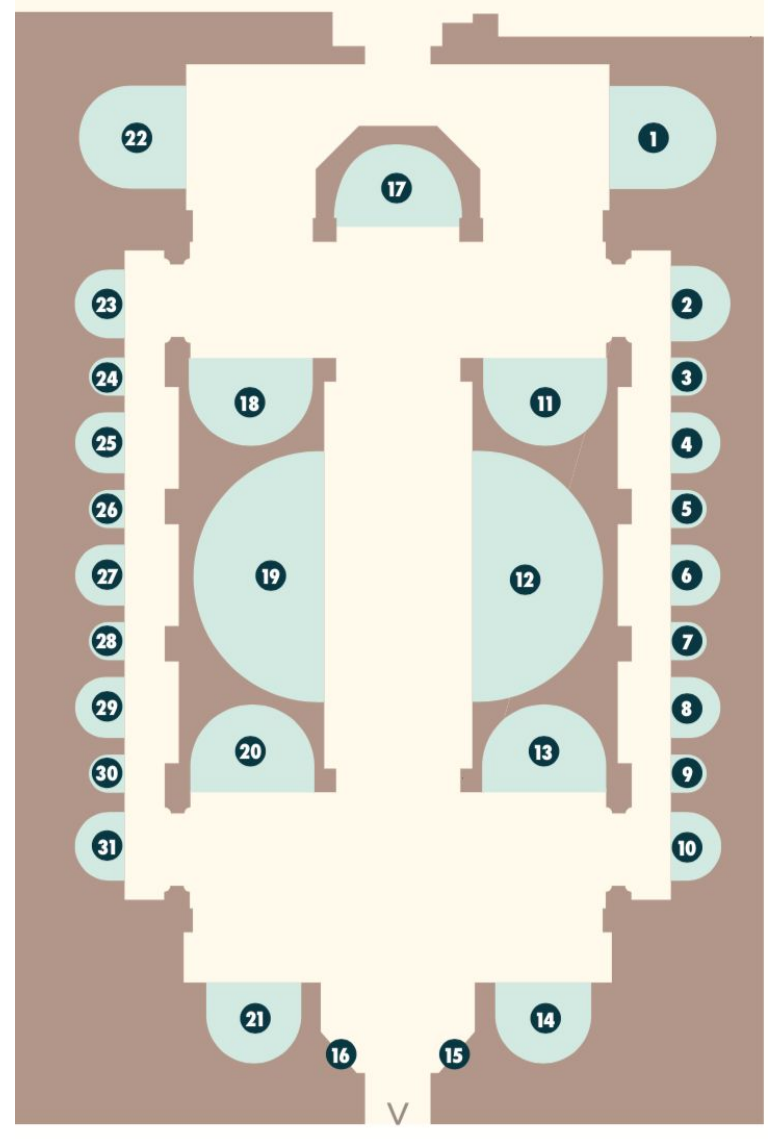

Theodore Roosevelt Memorial Hall

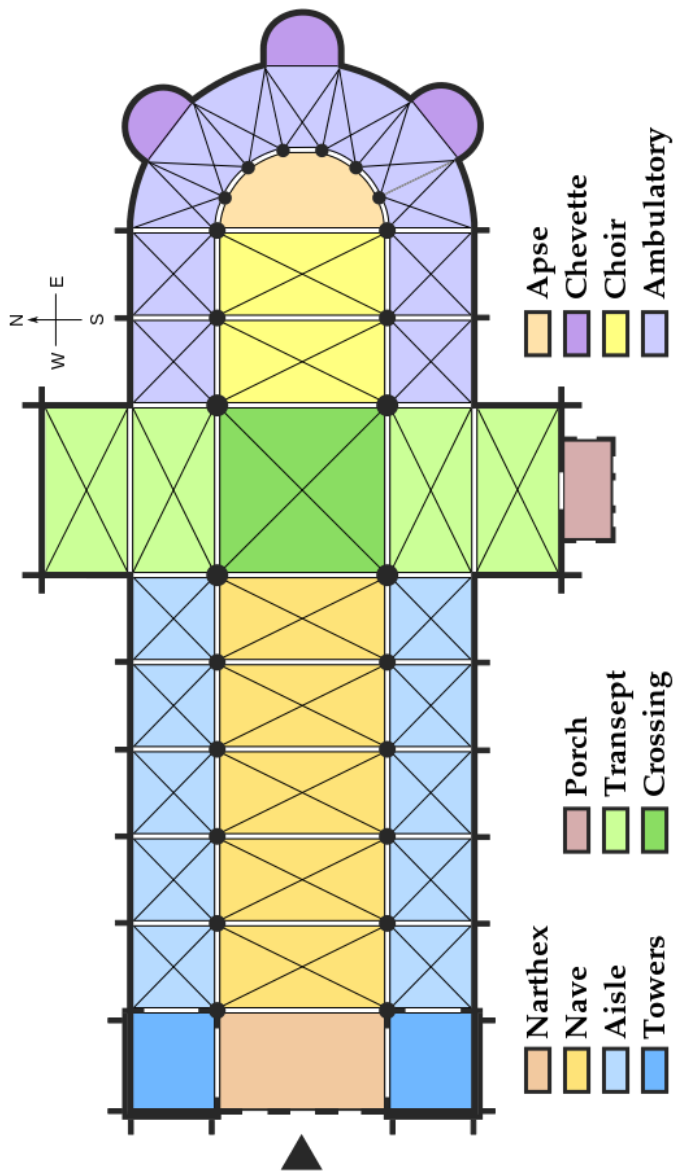

Figure 2. Left, Floor plan of the Hall of North American Mammals. Hall of North American Mammals Educator's Guide, American Museum of Natural History; right, floor plan of a typical basilica. Schematic illustration by Leonce49 and imitating Cathedral schematic plan.PNG under GFDL by Lusitania and TTaylor, January 29, 2010. Wikimedia Commons.

Building upon the atmosphere created by the previously established visual conventions present in cathedrals, the immersive qualities of the Hall of North American Mammals further mimic its more spectacular counterpart, the panorama. In the nineteenth century, the panorama was a popular form of entertainment. Painted on an enormous swath of canvas, their creators aimed to faithfully reproduce famous places or events, real or mythical. Early panoramas were composed of a structure that housed a cylindrical painting which visitors could see by ascending 
a staircase up to a circular observation deck, so that they would feel as if they were standing in the place and time that the painting depicted (see Figure 3). Subjects for panoramas were often chosen for their grandiosity, scenes recreated from famous battles, famous pilgrimage sites, or exotic, faraway lands were popular subjects and were rendered at a larger-than-life scale, as "audiences, it felt, would fully appreciate the illusionistic effect of the panorama only if its subject matter was ontologically linked to ideas of grandness and monumentality; in other words, the locations and events painted by panoramists had to resonate as suitable subjects for this epic mode of representation: 'big subjects for big pictures."' Thus, the panorama gave the viewer a sense of omniscience, enveloping them in an artificial reality where the limits of reality and fantasy were eliminated. The elements of presentation that make the panorama and by extension, the habitat diorama an immersive experience are numerous. First, this type of spectatorship is signalled by the larger-than-life scale of the scene. Second, the immersive experience heightens the sense of putting the viewer into a new place and time, "its invocation of presence as a constituent feature of the panoramic experience," and tied to that, it holds a "status as a mode of virtual transport." Further, "the quasi-religious nature of the exhibition space," and its power to invoke a sense of wonder and awe from the viewers, incite conversation in "hushed tones," reminiscent behaviour of being in a church. ${ }^{59}$

\footnotetext{
${ }^{59}$ Griffiths, Shivers Down Your Spine, pp.
} 


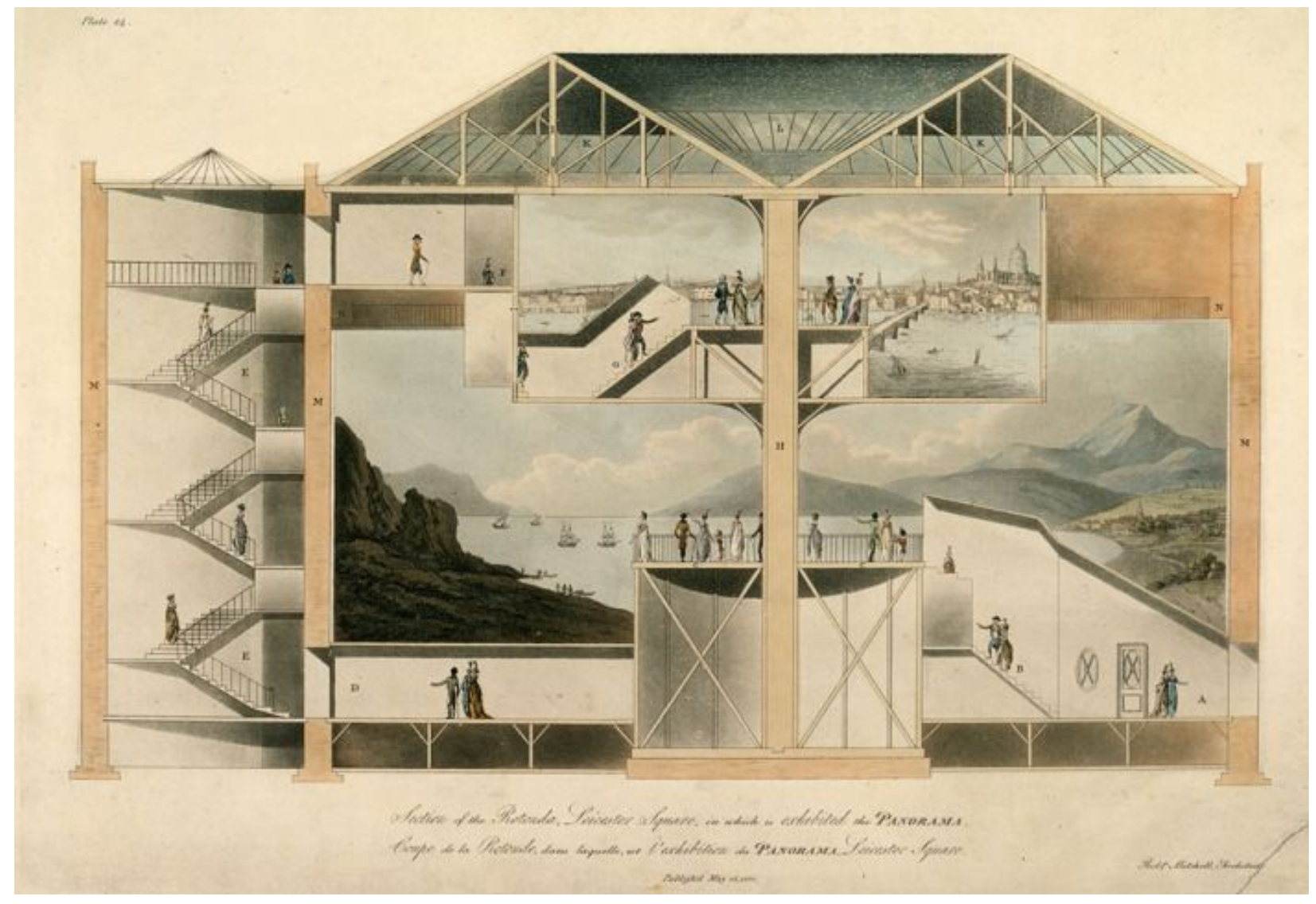

Figure 3. Cross-section of the Rotunda in Leicester Square that housed the panorama of London, 1801. The Bridgeman Art Library.

Moving from the spiritual towards the secular, the similarities between the panorama and diorama are even more pronounced than those between the diorama and cathedral. Much like the panorama, the habitat diorama is constructed with the viewer's eye to be level with the horizon line, inviting them to gaze into a nearly visually infinite distance on a grandiose landscape. Whereas a panorama places the viewer that the centre of the space they are being immersed in, the large window of a diorama invites voyeuristic behaviour from its viewers, who immerse themselves into the scene as a hidden bystander behind the glass. Both spaces virtually transport 
the viewer to new places and times through incredibly detailed renderings of the places they are representing. This sense of travel to a far-off location is even heightened in the diorama space, which strives to reproduce scenes with exacting detail down to the inclusion of three-dimensional material like dried plant specimens from each area depicted in addition to the taxidermied animals that are the focus of each composition. The Hall of North American Mammals transports visitors to the grandest landscapes across the North American continent and across time to a mythical point of Western human contact with the untouched land, as Harold Anthony wrote in Natural History magazine to announce its opening, "the new hall will bring to New York an impressive series of vistas into the best of primeval North America." ${ }^{60}$ Nineteenth century panoramas aspired to evoke the sublime and a sense of presence from the visitor through their massive size, "in this era of colonial and technological expansion ... panoramas offered spectators vicarious identification with the players of history and a privileged vantage point on some of nature's most prized beauty." 61 The Hall of North American Mammals brings its visitors on a tour of famous scenic landscapes that have been preserved in the national parks from the perspective of predetermined distant viewpoints, allowing each space to be scaled down to life size. Another form of "privileged vantage point," being able to approach the window of a diorama increases the intimacy of the experience and invites the visitor to stop and gaze at the animals up close, creating a safe, fictional communion with nature on an individual level akin to the ideal nature experience of the nineteenth century. ${ }^{62}$

The immersive experience created in the Hall of North American Mammals serves a dual purpose as Wonders describes, "a lesson in ecological awareness and propaganda [tool]." The

\footnotetext{
${ }^{60}$ Harold Anthony, “A Grand Tour of America,” Natural History 49 (April 1942), 189.

${ }^{61}$ Griffiths, Shivers Down Your Spine, 77.

${ }^{62}$ Haraway, Teddy Bear Patriarchy, 23.
} 
year the hall was declared finished and dedicated in 1954, the guidebook explained its mission to spectators: "The visitor sees the animal at home, he appreciates the relationship between the environment and the kind of creature that can live in it, and he is brought to realize the necessity of preserving such environments if the animals themselves are not to be driven out of existence. Thus, both the aims of education and of conservation are served." ${ }^{93}$ While the study of ecological systems as opposed to individual organisms germinated in nineteenth century biology, the field of ecology rose to prominence in the mid-twentieth century and as John Tresch explains, "dioramas conveyed a dynamic and relational understanding of both species and individuals, showing organisms as part of habitats formed by specific vegetative, geological, and meteorological features. ${ }^{96}$ This was also in part due to demand from within the museum: visitors, curators, and scientists had become dissatisfied with static specimen displays that provided little contextual information. Quinn notes, "They wanted a more complex, accurate, and entertaining way to convey habitat, behaviour, ecology, and environmental issues and concerns." ${ }^{65}$ Additionally, as the 1942 Annual Report states, "the traditional method of displaying museum objects according to their academic classification rather than their dynamic relations in nature tends to produce in the minds of visitors a feeling of remoteness between museum interests and the contemporary problems of today." ${ }^{66}$ The immersive experience of visiting the Hall of North American Mammals also encouraged an emotional appeal from visitors, which was important for scientists and curators who wanted greater support for the conservation movement. Wall text was

\footnotetext{
${ }^{63}$ American Museum of Natural History, General Guide (New York: American Museum of Natural History, 1954) 134.

${ }^{64}$ Berkowitz and Lightman, Science Museums in Transition, 265.

${ }^{65}$ Quinn, Windows on Nature, 15.

${ }^{66}$ American Museum of Natural History, Annual Report 1942 (New York: American Museum of Natural History, 1942) 17.
} 
eliminated from the design of the hall so it would not interfere with what Quinn calls "the intended illusion of a wilderness experience. ${ }^{97}$ While some museum scientists believed that the diorama halls held little educational value, "the majority endorsed these exhibits as the best means to turn visitors on to science by replicating that sense of awe, wonder, and discovery that nature engenders. ${ }^{168}$ As awe-inspiring as they may be, the dioramas within the hall cannot ever truly replicate the experience of being out in nature that the museum may have intended. By creating a safe space to face many species of animals that in the wild would prey on a human, the hall reinforces an anthropocentric understanding of nature that is governed by its human dominion. This experience simultaneously breaks the rules of any wildlife encounter while attempting to create a "copresence" between the visitor and animal within an idealized environment.

Through the larger-than-life scale presentation and virtual transport to another place and time in each diorama window borrowed from the panorama, along with the reverent behaviour elicited by the architectural atmosphere and layout borrowed from the cathedral, the Hall of North American Mammals constructs an immersive experience that mimics a particular vision of the ideal nature experience for its visitors. This is accomplished through lifelike and dynamic animal taxidermy inside a specially constructed stage, but the success of each diorama's performance is dependent on the illusionistic power of the landscape painting that makes up each scene's setting. ${ }^{69}$ These landscape paintings draw from a body of artistic work produced by the

\footnotetext{
${ }^{67}$ Quinn, Windows on Nature, 19.

${ }^{68}$ Quinn, Windows on Nature, 19.

${ }^{69}$ More detailed documentation on the technical details of constructing habitat dioramas has previously been written by Stephen C. Quinn in Windows on Nature and Karen Wonders in Habitat Dioramas.
} 
Hudson River school during the nineteenth century that concretized the particular landscape of majestic, pristine wilderness as the apex of nature in the mind of the American public.

\section{Artistic inspiration: the Hudson River school and Frederic Edwin Church}

Somewhat surprisingly, the medium of photography was never employed in this hall as a more scientifically objective method of representing the North American landscape. ${ }^{70}$ Diorama painter James Perry Wilson notably held the opinion that photographic technology at the time was not advanced enough to capture the light and colours properly, stating that "you can't rely on photographs, even the best color film, to record the color exactly as the eye sees it." ${ }^{\prime 11}$ This opinion relies on the false belief that the mechanical objectivity of the camera represents the most realistic and truthful image. This belief assumes that further intervention by the photographer to properly colour and expose the photo is inherently untruthful, despite it being a necessary step in the printing process. ${ }^{72}$ To produce the 'correct' colours Wilson was so preoccupied with, it would be necessary to adjust exposure settings or tint a black and white print, which he would think was counterintuitive to the goal of objectively representing the landscape. Using the monumental photography of Edward Burtynsky as an example, it's entirely possible to depict highly-detailed and vividly coloured "true" representations of landscapes that

\footnotetext{
${ }^{70}$ Photography is often displayed in the newer halls in the museum in complicated display structures as scientific evidence that teaches visitors how to analyse the objects on display. In the museum's research, visual evidence has progressed much further past traditional photography as a research method, marked by the presence of the Microscopy and Imaging Facility lab. For more information, see "About Us," American Museum of Natural History, https:/www.amnh.org/our-research/microscopy-and-imaging-facility/about-us

${ }^{71}$ Wilson, J. P. circa 1958. Unpublished interviews conducted at the Peabody Museum of Natural History by Rudy Freund and Rudy Zallinger, transcription xerox, American Museum of Natural History archives, quoted in Michael J. Reiss and Sue Dale Tunnicliffe, "Dioramas as Depictions of Reality and Opportunities for Learning in Biology," Curator: The Museum Journal, vol. 54, no. 4 (2011) 346.

${ }^{72}$ For more on the myth of photographic objectivity, see Marita Sturken and Lisa Cartwright, Practices of Looking (Oxford: Oxford University Press, 2001) 16-21.
} 
are reproducible at a massive print size. ${ }^{73}$ However, there are practical technical limitations to using photography in the hall: it would be difficult to create a panoramic print of the landscape that was distorted to accommodate the trompe l'oeil illusion of three dimensional, receding space and perhaps more importantly, the print would fade very quickly under the lighting of each diorama. While photography could ultimately be the most objective method of representation due to its ability to accurately record pictorial detail, it would have required much more effort and upkeep than painting. Photography was extensively used by the artists alongside plein air watercolour and pencil sketches in the data-collecting process on expeditions but ultimately painting is the chosen medium to depict the diorama background landscapes. In this medium, the artist can take certain liberties with the overall composition, colour, and dramatic atmosphere as long as the correct natural processes and biotic elements are represented. These liberties give the painter an ability to imbue a landscape with the necessary emotional resonance.

The Hall of North American Mammals is painted in a style that transcends realism, featuring famous scenic natural wonders that sit behind an illusory recessive field, overloaded with minute biotic details appropriate for each location, and swirling, dramatic atmospheres that showcase natural phenomena. ${ }^{74}$ In Windows on Nature, Quinn repeatedly draws connections between the artistic techniques used by the museum's diorama painters and those of Renaissance artists while ignoring any association with nineteenth century American landscape painters. ${ }^{75}$ In contrast, other scholars such as Karen Wonders, Karen Rader, and Victoria Cain situate the American habitat diorama painting style within a history of American landscape painting that

\footnotetext{
${ }^{73}$ Edward Burtynsky is a Canadian photographer known for his work depicting industrial, urban, and natural landscapes. For further information, see http://www.edwardburtynsky.com/.

${ }^{74}$ For example, the precisely calculated sunset in the Jaguar diorama, or the aurora borealis in the Wolf diorama.

${ }^{75}$ Quinn, Windows on Nature, 10.
} 
developed in the nineteenth century. While Quinn correct in comparing techniques employed by the museum artists to the Renaissance period, scores of artists since the 1400s have been employing the same atmospheric and mathematical perspective rendering techniques to their work. The subject matter and stylistic qualities of American landscape painting through the nineteenth century thus provide a more robust context for understanding the diorama backgrounds in the Hall of North American Mammals.

The most recognised group of American landscape painters to embody the beauty and danger of nature, or its disappearance, during the nineteenth century were the Hudson River school. The school, as it has come to be known but was not formalized in any way at the time, was established in the early nineteenth century by Thomas Cole. Cole was an English immigrant who popularized a dramatic style emblematic of his inspiration from the British aesthetic theory of the Sublime in nature, which was unprecedented in other American art. ${ }^{76} \mathrm{He}$ rose to fame in New York in 1825 selling his paintings to a wealthy, cosmopolitan audience. His popular appeal lied in the dramatic and dynamic brushwork and composition which evoked an emotional response from viewers, unlike past realist work "depicting specific views with banal accuracy and bland pictorial harmony." ${ }^{77}$ He strongly felt that the depiction of nature in the new nation would establish an American cultural identity. Being a devout Christian, he believed that he was the one to do it by virtue of his God-given artistic abilities. ${ }^{78}$ Tricia Cusack writes, "The [subsequent] formation of national identity in nineteenth-century America depended on a

\footnotetext{
${ }^{76}$ Kevin J. Avery, “The Hudson River School,” in Heilbrunn Timeline of Art History (October 2004) http://www.metmuseum.org/toah/hd/hurs/hd_hurs.htm

77 Angela L. Miller, "The Fate of Wilderness in American Landscape Art: The Dilemma of 'Nature's Nation," in $A$ Keener Perception: Ecocritical Studies in American Art History, ed. Alan Braddock and Christoph Irmscher (Tuscaloosa: The University of Alabama Press, 2009), 89.

${ }^{78}$ Metropolitan Museum of Art, American Paradise: The World of the Hudson River School (New York: H.N. Abrams, 1987) 23-24.
} 
Christian ethos that was enshrined in Hudson River school art and closely associated with the image of the wilderness" as Cole and later, his fellow painters, sought out subjects for his art for both its aesthetic qualities as well as moral lessons from nature. ${ }^{79,80}$ Cole also feared the consequences of the industrialization that was proliferating across the country. Environmental concern was a large part of Cole's ethos as a painter, interpreted in a similar way as George Perkins Marsh. His understanding of nature was largely grounded in an appreciation for pristine wilderness as he witnessed the Industrial Revolution. "Improvement" was changing the face of the land and Cole saw it as a problem, writing in American Monthly Magazine, "the ravages of the axe are daily increasing - the most noble scenes are made desolate, and oftentimes with a wantonness and barbarism scarcely credible in a civilized nation." ${ }^{\text {81 }}$ Cole painted both the idyllic existing landscapes around the Hudson River and allegorical pieces to illustrate his concern for the disappearance of nature amidst the Industrial Revolution. His famous Course of the Empire, depicts the rise and fall of a civilization that, upon ruining itself, becomes reclaimed by the natural environment. Other painters, like Cole's pupil Frederic Edwin Church, were less interested in the ecological benefits of maintaining areas of untouched wilderness and more focused on their powerful and iconographic qualities, using a method of documentation grounded in scientific practices to show viewers the natural beauty of remote locales. Where Thomas Cole painted locally cherished and allegorical landscapes, Church found the a similar symbolic power in South America and the Arctic.

\footnotetext{
${ }^{79}$ Cusack, "The Chosen People," 26.

${ }^{80}$ Harvey K. Flad, "The Parlor in the Wilderness: Domesticating an Iconic American Landscape," in Geographical Review, vol. 99, no. 3 (July 2009) 356.

${ }^{81}$ Thomas Cole, "Essay on American Scenery," in American Monthly Magazine (January 1836) 12.
} 
Within his lifetime, Church popularized a dynamic, romantic realist style associated with the Hudson River school and found fame amidst a public that reached beyond the art world. $\mathrm{He}$ made the style of the school and the dominant image of nature recognizable to everyone by presenting his massive paintings in a spectacular way that mimicked the popular moving panorama presentations of the late nineteenth century. ${ }^{82}$ When he was 18 , Church began studying under the guidance of Thomas Cole and quickly became his best pupil due to an extraordinary ability to draw and paint realistically. After his time with Cole, Church began working from a New York City studio and gained a reputation for painting in a romantic realist style centred around intensely detailed synthesized landscapes drawn from studies of real places, as opposed to Cole's allegorical landscapes ${ }^{83}$ For Church, scientific knowledge was more than an interest and became an essential subject of inquiry in the artist's work. Church was captivated by Alexander von Humboldt's writing in Cosmos (1845), which urged both artists and scientists to travel through and document the landscapes of South America. He travelled to the continent soon after, producing the massive ten foot by five foot painting, Heart of the Andes as a result (see Figure 4). Expeditions thereafter became part of his modus operandi, first travelling with scientists on their expedition to extensively document the natural processes that characterized remote lands through South America and later by chartering his own expedition to the Arctic. ${ }^{84}$ His popularity began to surge, and by 1857 , the announcement of his single-painting exhibitions

\footnotetext{
${ }^{82}$ Unlike the cylindrical panoramas discussed above, later panoramas were displayed as a long, flat sheet rolled onto two spools. By turning the spools, the canvas would advance and tell a visual story from within a single large frame. For further reading, see Griffiths, Shivers Down Your Spine.

${ }^{83}$ Kevin J. Avery, "Frederic Edwin Church (1826-1900)," in Heilbrunn Timeline of Art History (August 2009) http://www.metmuseum.org/toah/hd/chur/hd_chur.htm

${ }^{84}$ Avery, "Frederic Edwin Church (1826-1900)."
} 
and their touring schedules in the United States and Great Britain were widely covered in the news. $^{85}$

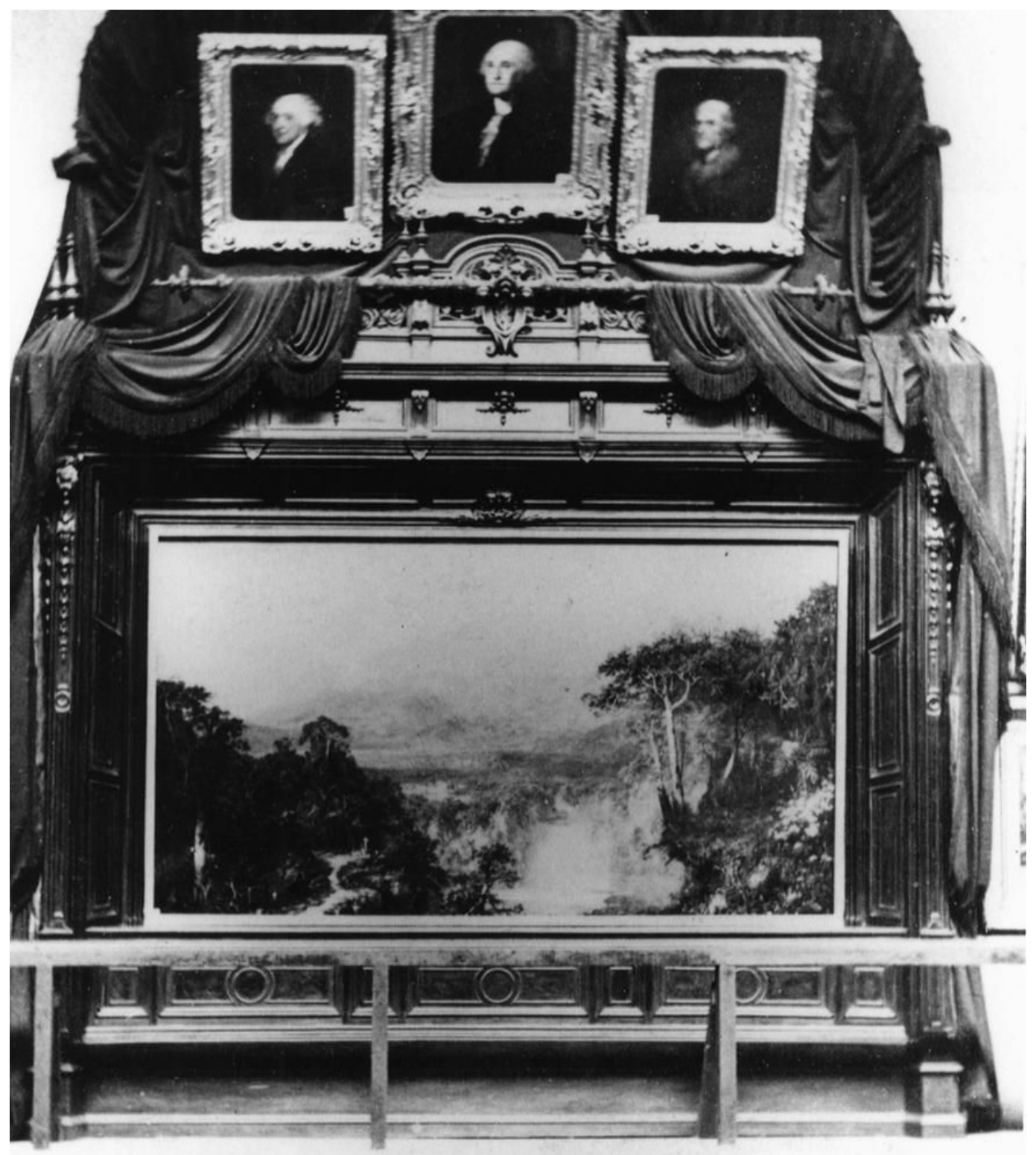

Figure 4. Installation view of the 1864 Heart of the Andes exhibition. Photograph by J. Gurney \& Son, NYC. New York Historical Society.

${ }^{85}$ Gerald L. Carr, In Search of the Promised Lands: Paintings by Frederic Edwin Church (New York: Berry-Hill Galleries, Inc., 2000) 15. 
Following the success of Heart of the Andes, Church chartered an expedition to explore the coast of Labrador and Newfoundland. with the goal of studying and sketching icebergs to bring the mythical scene back to the American people, a subject no other artist had attempted from real life observation. ${ }^{86}$ Church brought along reverend Louis Legrand Noble, a fellow naturalist friend who had also written a comprehensive biography on the artist's predecessor Thomas Cole and the pamphlet that accompanied the exhibition of Heart of the Andes. Noble's task was to document the entire journey and was later published in a massive, 300 page book entitled After Icebergs with a Painter: A Summer Voyage to Labrador and Around Newfoundland. The book was announced in late 1860 and printed the following year as its painted counterpart was being finished. The volume featured colour illustrations based on Church's sketches alongside Noble's essays as a small preview of what was to come. The book contributed not only to popular polar literature of the time but also drummed up publicity for the reveal of The Icebergs (see Figure 5). ${ }^{87}$

Timothy Mitchell argues that Church was primarily interested in depicting the scientific advancement that came with Arctic exploration rather than the landscape as it actually existed, as indicated by the presence of an erratic boulder resting atop a protrusion of ice in the centre of his composition. In this case, other thematic elements typical of the Hudson River style like "divine majesty" and "dangerous adventure" took a backseat to this one. Church went so far as to avoid suggestions of a political or religious interpretation on the painting's original broadside announcement, instead only highlighting the faithful reproduction of each minute detail and its

\footnotetext{
${ }^{86}$ Timothy Mitchell, "Frederic Church's 'The Icebergs': Erratic Boulders and Time's Slow Changes," in Smithsonian Studies in American Art, vol. 3, no. 4 (Autumn 1989) 3.

${ }^{87}$ Dallas Museum of Art, "Louis Legrand Noble's After Icebergs with a Painter (1861)," https://collections.dma.org/essay/5ndk60Yx
} 
underlying natural phenomenon that caused it. ${ }^{88}$ The presence of the boulder represents contemporary scientific controversy at the time, as scientists didn't know how to explain the presence of erratics that were frequently found on icebergs within the parameters of accepted scientific theory. ${ }^{89}$ Mitchell describes Church as an artist-as-scientist: the painter spent an extensive amount of time talking to contemporary scientists and explorers about their travels to figure out the best locations for spotting icebergs, and when he got there, he produced hundreds of detailed sketches of natural phenomena around the icebergs. His final work was somewhere between allegory and faithful reproduction; like he did in Heart of the Andes, Church used his many sketches to condense all of the characteristics of an iceberg into one immensely detailed image. He relied on a composition of multiple elements from an existing location that included natural processes that scientists were studying and had written about in their accounts: terrace lines, caves, and seams. As Mitchell notes, "By choosing to include the iceberg's terrace lines in his painting, Church linked his image to one of the most frequently observed and recorded phenomena of the North. ${ }^{" 90}$ Instead of depicting humans and animals to form a total documentation of the Arctic landscape, Church highlighted the erratic boulder and depicted other geologic details emblematic of the scientific debates that were of primary interest to him. Church's ability to faithfully render the details of natural processes that were endemic to a specific geographical area while composing a visually cohesive and aesthetically pleasing landscape scene reveals the possibility that scientifically-informed art can effectively serve as an educational tool without being overtly didactic and still hold emotional appeal with a viewer.

\footnotetext{
${ }^{88}$ Andrew Wilton and T. J. Barringer, American Sublime: Landscape Painting in the United States, 1820-1880 (Princeton: Princeton University Press, 2002) 224.

${ }^{89}$ Mitchell, "Boulders and Slow Changes," 4.

${ }^{90}$ Mitchell, "Boulders and Slow Changes," 9-11.
} 
Critics of Church's work complained of its overwhelming detail, but in fact Church was

eliminating unnecessary elements and bringing attention to the specimens and processes he felt were important to understanding the ecological history of a place. ${ }^{91}$ Thus, The Icebergs is not only an example of the power that remote pristine wilderness areas have held on the American imagination, but also presents a particularly relevant precedent for the diorama painters at the Museum of Natural History to follow in their own pursuits as artist-scientists.

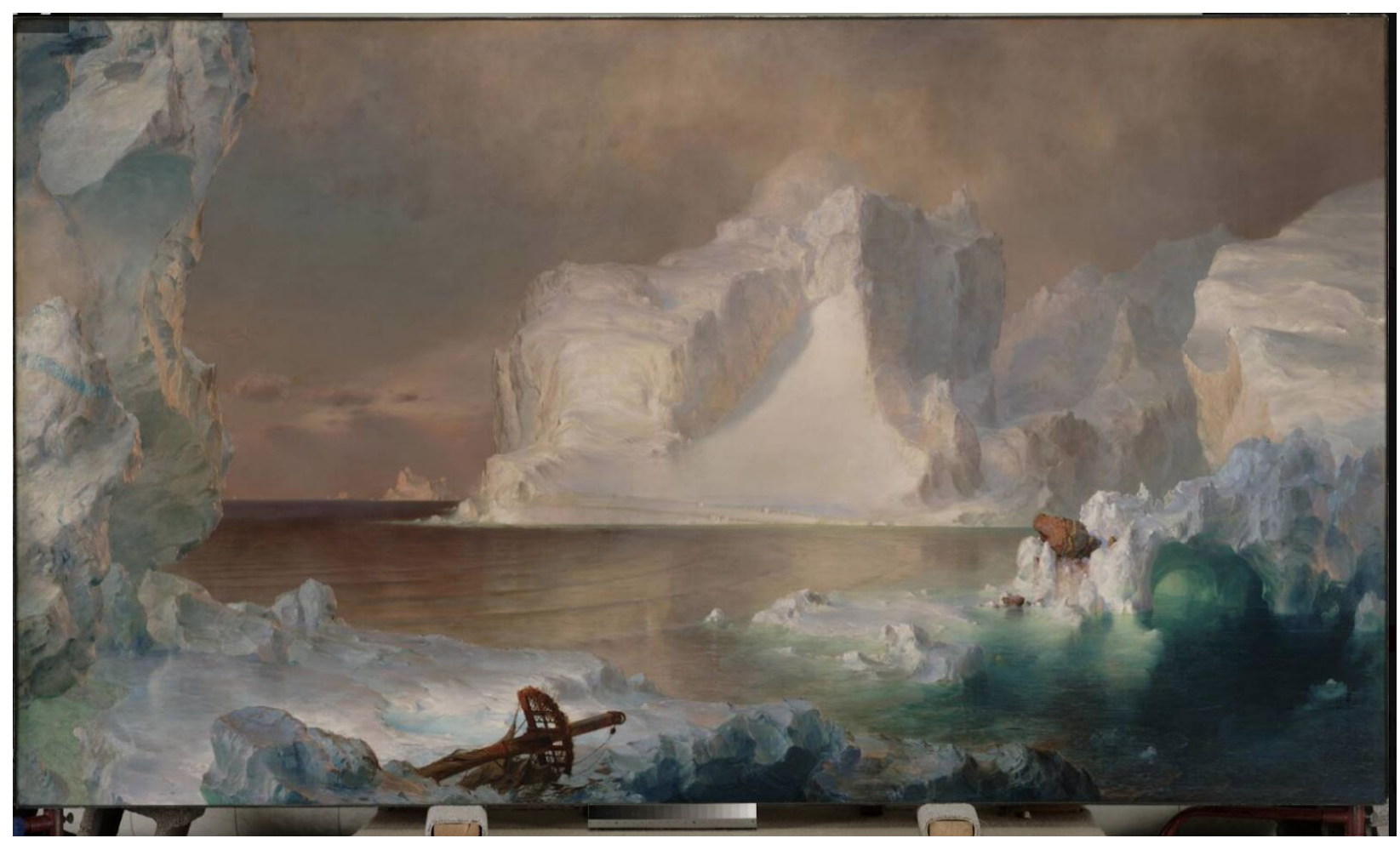

Figure 5. Frederic Edwin Church, The Icebergs, 1861. Oil on canvas, 85 x 133 inches. Dallas Museum of Art.

\footnotetext{
${ }^{91}$ Jennifer Raab, Frederic Edwin Church: The Art and Science of Detail (New Haven: Yale University Press, 2015)
} 8. 
The first generation of museum diorama painters began their careers during the end of the popular reign of the Hudson River school in the 1880s and 1890s. At this time, many museum artists such as Belmore Browne, Charles J. Hittel, William R. Lee, and Carl Rungius attended European art academies such as the Académie Julien in Paris, the Royal Academy of Fine Arts in Munich, and the German Academy of Art in Berlin, in place of or in addition to American art schools before working for the museum. It was also possible for artists with a keen eye for detail to be self-taught; museum painters Francis Lee Jaques and James Perry Wilson never attended art school nor were they known to have studied under established mentors. Other artists following this first generation of masters were also instructed by their predecessors in lieu of attending formal education, for example, Belmore Browne's son George was instructed by his own father. ${ }^{92}$ By the time the first generation of diorama painters were beginning their careers, the Hudson River school and the romantic realist painting style they employed was falling out of favour in lieu of the nascent forms of abstracted, modern art. However, academies continued to educate their pupils in traditional manners, and the academicians of New York did not completely disappear. It's possible the diorama painters, in addition to being avid nature enthusiasts and, as Church had been, thoroughly scientific in their approach to painting were led to seek out these detailed paintings from within the collection of prominent museum members or the Metropolitan Museum of Art. The Met held one of the last major retrospectives of a Hudson River school painter after Frederic Edwin Church's death in 1900. Fifteen years later, the museum acquired a large group of Hudson River school paintings upon the death of former AMNH president, Morris K. Jesup. ${ }^{93}$ Nonetheless, the connection between the Hudson River

\footnotetext{
${ }_{92}$ Quinn, Windows on Nature, 171-172.

${ }^{93}$ Robert W. De Forest, Report of the Trustees for the Year Ended December 31, 1915 (New York: The Metropolitan Museum of Art, 1915) 17.
} 
school and AMNH's Hall of North American Mammals is clear because the landscape painters like Thomas Cole and Frederic Edwin Church defined an iconography of nature with their work. Their visual lexicon became recognisable even outside of the art world, since they were so popular during their lifetimes. Thus, it follows that the artists at the museum would later mimic the style of the HRS because a larger public already associated it with the concept of nature as untouched wilderness. As Angela Miller argues,

\begin{abstract}
What is most significant in the present context ... is that these ideas were conveyed to a broad audience through representations of nature more powerfully than the "real" thing itself. And by midcentury, the representation of nature had become codified in a set of mythic narratives, spatial conventions, and communal symbols. Landscape viewing evolved into a specific kind of cultural practice: an act of public spectatorship in which crowds of people stood poised before large-scale works that demanded to be read part by part, like an unfolding story. ${ }^{94}$
\end{abstract}

Coupled with phenomena like the magisterial gaze, which positions the viewer as an intrepid explorer discovering new lands, the Hudson River school turned the American wilderness into a hegemonic image that dominated the public's imagination whilst they, as Cusack notes, "symbolically erased Native Americans by presenting the Hudson Valley as empty territory." Painting in this style communicates and reinforces a specific type of appreciation for nature that considers pristine wilderness to be the apex of natural environments that is to be observed through the Western colonial explorer's perspective. By effectively refusing to depict human presence in these wild landscapes, the Hudson River school contributed to a false binary separation between the human environment and the natural one. ${ }^{96}$

\footnotetext{
${ }^{94}$ Miller, "The Fate of Wilderness," 86.

${ }^{95}$ Cusack, "The Chosen People," 55.

${ }^{96}$ Miller, "The Fate of Wilderness," 102.
} 


\section{Politicizing nature: support for the national parks}

The presence of many landscapes within national parks gives the Hall of North American Mammals further cultural power. Here, the museum literally represents nature as unchanged at the specific point of European contact through the creation, presentation, and preservation of the Hall of North American Mammals. "The wilderness, staged as an object of nostalgia, still plays an important role in American culture, symbolized, for example, by the western in film and by the national parks" ${ }^{" 97}$ Despite being renowned for their contribution to biological conservation efforts today, the national parks originally were not preserved out of altruistic concern for the environment but instead the establishment of the first national park came about largely due to corporate interests from stakeholders in western expansion like the Northern Pacific Railroad Company. The association between conservation efforts and the museum seems to be a connection made after Carl Akeley applied the national park idea to his desire to save tracts of wilderness in Africa.

Although the members of the Hudson River school, like Thomas Cole, and other romantic naturalists and intellectuals were, as Richard West Sellers notes, "voicing concern about the preservation of nature and decrying the exploitation of natural resources," the establishment of Yellowstone National Park preceded the emergence of a unified American conservation movement. ${ }^{98}$ Established in 1872 , the park was "reserved and withdrawn from settlement, occupancy, or sale under the laws of the United States, and dedicated and set apart as a public park or pleasuring-ground for the benefit and enjoyment of the people; and all persons who shall locate or settle upon or occupy the same, or any part thereof, except as hereinafter

\footnotetext{
${ }^{97}$ Cusack, "The Chosen People," 55.

${ }^{98}$ Richard West Sellers, Preserving Nature in the National Parks: A History (New Haven: Yale University Press, 2009) 7 .
} 
provided, shall be considered trespassers and removed therefrom." The Yellowstone area was accessed easiest from the north, forking out from a planned westward route of the Northern Pacific Railroad Company (NPRC), and the railroad believed it could monopolize tourist travel through the area. NPRC supported the Washburn-Doane Expedition, "a largely amateur party organized to investigate tales of scenic wonders in the area," ${ }^{99}$ and subsidized work by Hudson River school artist Thomas Moran to be displayed at the Washington Capitol as part of the effort to establish the park. As Sellers explains, Yellowstone "provided not only the first but also the most enduring image of a national park: a romantic landscape of mountains, canyons, abundant wildlife, and fantastic natural phenomena. ... Moreover, the spacious, majestic scenery being preserved ... aroused a strong sense of patriotism and a romanticized pride in America's most dramatic landscapes, helping stimulate national tourism and the park movement." ${ }^{100}$ The powerful imagery of the park concretized the idea of the national parks system in the public mind and was strengthened when president Theodore Roosevelt backed the parks as a democratic space, for all Americans to visit as travel across the country became easier in the early twentieth century. ${ }^{101}$ The Yellowstone Park Act protected the park from "wanton destruction of the fish and game" and promoted "preservation, from injury or spoilation, of all timber, mineral deposits, natural curiosities, or wonders within said park, and their retention in their natural condition."102 Thus, Sellers argues, the preservation of land that fit within the image of romantic and pristine wilderness for all people to use became the core of the national park idea, "endowing it with high idealism and moral purpose as it spread to other areas of the country and ultimately around the

\footnotetext{
${ }^{99}$ Sellers, Preserving Nature, 8.

${ }^{100}$ Sellers, Preserving Nature, 12-13.

${ }^{101}$ Sellers, Preserving Nature, 14.

102 Tolson, Laws Relating to the National Park Service (1933), 26-27. Quoted in Sellers, Preserving Nature, 14.
} 
world." ${ }^{103}$ However, the advances in ecological science during the late nineteenth century had little relationship with the establishment of these great tracts of 'undisturbed' land. While scientists would conduct research in them, ecological concerns were largely not part of parks management until the mid-1960s. Seeing the potential of a booming tourism market, management across the parks quickly established a bevy of hotels, resorts, and spas to serve park patrons, along with all of the necessary infrastructure, in strategically placed locations next to scenic features. Trails were maintained in select areas, and tracts of land not used in the trail systems were essentially ignored. While these scenic areas were the original target of the parks' preservation goal, people also enjoyed wildlife sightings and that became a significant draw for casual and sporting visitors alike. Charismatic megafauna attracted the most visitors, and as a result early national park wildlife policy focused on protecting impressive animals like bears and ungulates. ${ }^{104}$ Preceding any cohesive conservation movement, in their early decades national parks had already framed a specific perspective of nature appreciation that centred on pristine wilderness landscapes and further, promoted support for a select group of publicly appealing animals to generate a sense of pride and national identity in the American public.

\section{Conclusion}

While key figures in the nineteenth century such as Thomas Cole and Carl Akeley were conscious of and vehemently against uncontrolled resource extraction, reflecting the earlier writing of George Perkins Marsh, during this time they did not form a cohesive American

\footnotetext{
${ }^{103}$ Sellers, Preserving Nature, 15.

${ }^{104}$ Sellers, Preserving Nature, 24.
} 
conservation movement. Cole, Church, and the other painters of the Hudson River school created a dominant iconography of nature and helped established the national parks through their depictions of these remote wilderness areas. What did emerge from this time period was the pride in and aesthetic appreciation of nature, more akin to the wonder and awe that Frederic Edwin Church strove to invoke in his paintings on his missions in the spirit of Alexander von Humboldt, and typified within the scenic landscapes of the national parks that held up pristine wilderness as the apex of nature, protected for the American public as a central element of the American national identity. While the parks were not initially sites of science-based conservation, the national park idea of preserving large tracts of 'untouched' wilderness later became associated with this conservation movement. When Carl Akeley needed to respond to the rampant expansion of American urbanization and resource extraction, he found a solution in the creation of national parks. Though he saw the African continent as the site of primary importance during his lifetime, the museum expanded this notion of conservation through display to North American in the Hall of North American Mammals along with the other diorama halls that were constructed in the mid-twentieth century.

The hall embodies and reinforces this understanding of nature that originated in the nineteenth century which separates the human from the natural through the segregation between land that is ripe for extraction and human abuse and land that is protected at all costs. The site of this wilderness is a remote place for the nonhuman and not to be permanently occupied by humans - although it can be visited in order to strengthen our appreciation of it - which is embodied by the US national parks. Support for the parks ideal of preserving this land in a state of 'primeval' or pristine wilderness. As Angela Miller states, "The late-nineteenth-century 
version of wilderness, with its insistence on expunging any human history or presence, merely pursued the romantic wilderness concept - grounded in the radical segregation of human and natural histories - to its logical extreme." ${ }^{105}$ This is particularly evident in the way the museum's artists chose to render the background paintings, which mimic the style of the Hudson River school landscape painters of the nineteenth century. Coupled with the immersive and reverent environment that the habitat dioramas and the hall that contains them create The Hall of North American Mammals remains a space that attempts to infuse this notion of separation in the name of environmental preservation, so central to American national identity, with a scientific understanding.

${ }^{105}$ Miller, "The Fate of Wilderness," 105. 


\section{The Garden: High Line}

"For the moment, the High Line has gone not to wrack and ruin, but to seed: weeds and grasses and even small trees sprout from the track bed. There are irises and lamb's ears and thistle-tufted onion grass, white-flowering bushes and pink-budded trees and grape hyacinths, and strange New York weeds that shoot straight up with horizontal arms, as though electrified."

Precedents: Central Park and the pastoral style

An antidote to the uninhabitable wilderness, the pastoral landscape of the garden is a naturalistic space intended for humans that melds nature and culture together. This is embodied by Central Park, the grandest architectural feature of New York during the late nineteenth century. The park's superintendent, Frederick Law Olmsted, and the landscape architect Calvert Vaux "admired the harmonious composition of English parks [and] found spontaneous manners as well as eclectic design distasteful," thus they envisioned this natural space within the city as "a unified work of landscape art." ${ }^{\text {"107 }}$ Olmsted believed that the city was the way for the United States to prosper as a country, writing in 1877 , “Our country has entered upon a stage of progress in which its welfare is to depend on the convenience, safety, order, and economy of lie in its great cities." ${ }^{108}$ Having been repulsed by the unruly pre-Civil War cities of the South, Olmsted believed that proper city planning inspired by natural processes (such as providing downhill water drainage systems) would bring a sense of community and order to its neighbourhoods, in addition to improving public health. Additionally, as Albert Fein notes, the park was meant to "demonstrate the cultural capacity of a free urban society," differentiated from the slavery

\footnotetext{
${ }^{106}$ Adam Gopnik, “A Walk on the High Line,” The New Yorker, May 21, 2001.

${ }^{107}$ Roy Rosenzweig and Elizabeth Blackmar, The Park and the People: A History of Central Park (Ithaca: Cornell University Press, 1992) 131.

${ }^{108}$ Frederick Law Olmsted, "Passages in the Life of an Unpractical Man," in F.L. Olmsted, Landscape into Cityscape: Frederick Law Olmsted's Plans for a Greater New York City (Ithaca: Cornell University Press, 1968$) 52$.
} 
economy Olmsted witnessed in the South. ${ }^{109}$ For Olmsted, the park served to democratize the city, giving its residents a naturalistic green space in which to take refuge from the city - New York at the time was loud, dirty, and unsanitary. As opposed to the rugged and wild national parks, it was also an opportunity to meld nature and culture by creating a space for "the progress of art and esthetic culture," allowing New York to blossom into the genteel city he imagined. ${ }^{110}$ This is evident in the consideration of the Arsenal building as a space for a future museum (which would become the first home of AMNH) under Olmsted's direction, the incorporation of the Metropolitan Museum of Art on Central Park land, and the numerous pieces of public art scattered through the park.

Under his direction, the landscape of Central Park was designed in the English pastoral style. This style represents a harmonized landscape where humans an nature can coexist. It is tame yet unconstricted which limits neither entity. Central to the design of the pastoral park is a network of elegantly curved paths that guide visitors through their journey. ${ }^{111}$ Alongside meadows, woodlands, and streams, Central Park is a delight to the curious explorer and is best experienced through visual encounters. Vignettes that incorporate predetermined scenic outlooks present an interplay of water features such as The Lake, The Reservoir, and Bethesda Fountain; cultural 'ruins' such as Belvedere Castle, the Obelisk, the Swedish Cottage, and Block House no. 1; and finally 'natural' geographic sights like Vista Rock, Sheep Meadow, and the Great Hill. ${ }^{112}$

\footnotetext{
${ }^{109}$ Olmsted attributed the competitive business culture, presence of slave ownership, and lack of government intervention to their dirtiness. See F.L. Olmsted, Landscape into Cityscape: Frederick Law Olmsted's Plans for a Greater New York City (Ithaca: Cornell University Press, 1968) for further reading.

${ }^{110}$ In a letter to his contemporary, Parke Godwin, Olmsted wrote that the park was "a democratic development of the highest significance and on the success of which, in my opinion, much of the progress of art and esthetic culture in this country is dependent." Olmsted to Parke Godwin, Aug. 1, 1858, Bryant-Godwin Papers, Manuscript Division, New York Public Library, reproduced in Olmsted, Landscape into Cityscape, 26.

${ }^{111}$ M. Norton Wise and Elaine M. Wise, "Reform in the Garden," in Endeavour, vol 26, no. 4 (2002) 154.

${ }^{112}$ Ironically, all of the rocks that give Central Park its distinctive landscape were transported in from outside the city.
} 
The High Line has much in common with Central Park, as journalist Tom Baker argues in a recent compilation of critical essays Deconstructing the High Line, "the [High Line] can be read as a contemporary example of pastoral landscaping, and idealised construction of a particular vision of nature, that of the 'urban wilderness,' which is ornamental in essence."113 However, what Baker ignores is that the High Line embraces and additionally transforms the pastoral style through an ecological lens, drawing upon rhetoric (visual and otherwise) that rose to the fore of public consciousness through the American environmental movement of the $1960 \mathrm{~s}$ and 1970s. Additionally, what he has deemed "ornamental" about the park may be better understood through a museological perspective that incorporates the basic premise of object preservation; that keeping the objects held within the park — in this case, mostly plants — intact is of the utmost importance to its visual display and function within an ethos of environmental sustainability. Just like the missions of Central Park and the National Parks have expanded past serving only human wants and needs and evolved into conservancy parks, the High Line was imagined and constructed with environmental stewardship in mind.

\section{History of the High Line}

The High Line as a structure has a long history, ever-evolving in physical form and purpose. In 1847, the City of New York authorized the construction of street-level railroad tracks that would serve the warehouses and factories on Manhattan's West Side. This brought a significant increase in traffic and fatal accidents, which became such a problem that by the turn of the 20th century, the sections of Tenth, Eleventh, and Twelve Avenues that served as a rail

\footnotetext{
${ }^{113}$ Tom Baker, "The Garden on the Machine," in Christoph Lindner and Brian Rosa, eds., Deconstructing the High Line: Postindustrial Urbanism and the Rise of the Elevated Park (New Brunswick: Rutgers University Press, 2017) 109.
} 
throughway became known as "Death Avenue" and its existence was protested against. The railroad, New York Central and Hudson River Railroad Company, hired men on horses to ride in front of trains to warn pedestrians of their approach using bright red flags, colloquially known as the "West Side Cowboys," as mitigation for the congestion problems. However, in 1924 the New York City Transit Commission issued an order to eliminate all street-level rail crossings from the northern Manhattan Spuyten Duyvil neighbourhood down to West 60th Street, beginning a three-year negotiation between the city and railroad that would end with the proposal to establish an elevated line from the 30th Street Yard down to Canal Street. "“The beginning of the death of Death Avenue' and ... one of the greatest public improvements in the history of New York," as The New York Times referred to it, began with paving over the existing street-level line and construction for the elevated line in 1931 and opened in 1934 to high praises. ${ }^{114} \mathrm{~A}$ cheerier alternative, the "Life Line of New York" snaked its way south through Lower Manhattan, often literally through specially-constructed loading docks inside warehouses. ${ }^{115,116}$

However, the Depression significantly reduced rail freight shipments and never fully rebounded, impacting the necessity of the High Line over time. The line was fully operational until the southernmost section was demolished in 1960. The entire line was shut down in 1980 amidst the growth of truck freight use that had steadily been increasing since World War II. ${ }^{117}$ In the mid-1980s, Chelsea, the neighbourhood that surrounds the High Line, gentrified drastically and quickly in the span of a couple decades. As art centres and galleries established themselves,

\footnotetext{
114 "MAYOR DEDICATES WEST SIDE PROJECT," New York Times, June 29, 1934.

115 Joshua David and Robert Hammond, High Line: The Inside Story of New York's Park in the Sky (New York: Farrar, Straus and Giroux, 2011) x-xi.

${ }^{116}$ David and Hammond, Park in the Sky, 145.

${ }^{117}$ Christopher Gray, "Streetscapes: The West Side Improvement; On the Lower West Side, Fate Of Old Rail Line Is Undecided," New York Times, January 3, 1988, Late edition.
} 
high-end retailers followed suit, stringing along fashion and design magazines by $1999 .{ }^{118}$ The gentrifying neighbourhood was ultimately essential in Joshua David and Robert Hammond's effort to have the High Line established as a public park. Through their organization, Friends of the High Line, which raises the vast majority of the High Line's yearly budget through solicited donations, David and Hammond successfully solicited money and support from the local gallery owners, other well-known art world figures, and famous celebrities within the fashion and film industries to give the park project media attention and establish its status as a cultural institution.

Aesthetic appreciation of the wild space that grew on the rail line after the structure had been abandoned was paramount to its success. David and Hammond visited the site for the first time in 1999, shortly after the first meetings they held to begin organizing their preservation efforts. "The wildflowers and plants had taken over. We had to wade through waist-high Queen Anne's lace. It was another world, right in the middle of Manhattan," recounts Hammond. ${ }^{119}$ Seeing the wildflower field was essential to convincing people that saving the structure was a worthwhile pursuit, which David and Hammond used to their advantage by bringing potential supporters of the project to the site: "Most people were moved by it. You brought them up, you showed it to them, and they would do anything for the High Line after that." ${ }^{120}$ Later, they commissioned photographer Joel Sternfeld to create a series of photographs documenting the abandoned space in all four seasons (see Figure 6). This series was published in a monograph alongside essays such as Adam Gopnik's “A Walk on the High Line,” which had also been published in The New Yorker in May 2001. Alongside this popular press coverage, widespread

\footnotetext{
118 David and Hammond, Park in the Sky, 4.

${ }^{119}$ David and Hammond, Park in the Sky, 12. It should be noted that Daucus carota, the wildflower known as Queen Anne's Lace, is native to Europe and was introduced to North America, see North Carolina State University, "Daucus carota," https://plants.ces.ncsu.edu/plants/all/daucus-carota/.

${ }^{120}$ David and Hammond, Park in the Sky, 13.
} 
public support for the project gained traction in the wake of the events on 9/11 as a positive, creative effort that community members could be involved in. ${ }^{121}$

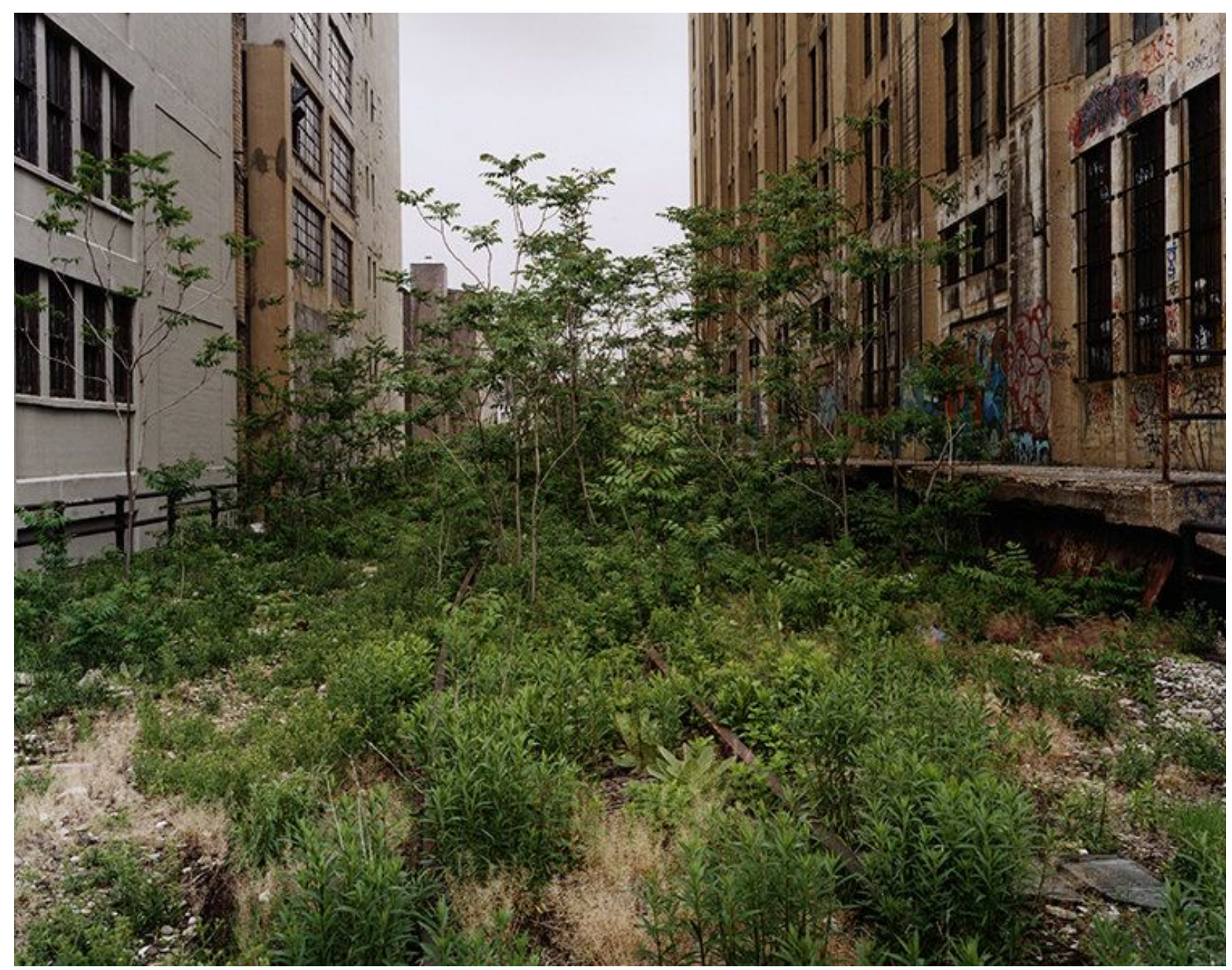

Figure 6. Ailanthus Trees, 25th Street, from the series Walking the Line. Photograph by Joel Sternfeld, May 2000. Friends of the High Line.

\section{Design of the park}

The High Line is less of an overtly scientific space than the Hall of North American Mammals, although science plays a role in its success. Where the museum is a space of science that uses art to evoke an emotional appeal in its display of science, the High Line conversely is

${ }^{121}$ David and Hammond, Park in the Sky, 39. 
an art space that's existence is justified or made more credible by the concept of environmental sustainability which permeated into the larger public sphere, and has thus created an "environmental aesthetic." 122 By playing on the core elements of the pastoral landscape embodied by parks of the nineteenth century like Central Park, the High Line renews this style by incorporating the environmental ethos that emerged in the 1960s and 1970s environmental movement into the design principles and style that guided the project and the language that is used to describe the park to visitors.

The park runs south from the 34th Street rail yards down to 14th Street at Gansevoort along an elevated second-story platform. Ascending the stairs from ground level at Gansevoort Street, full of American art, pancakes, window shopping, or the most delicious butter cake ice cream in the world, the steps open up to a small woodland overlook, dwarfed by the surrounding architecture formed by a warehouse, the Whitney Museum of American Art, and the Standard Hotel. Instead of a winding dirt trail, the entire park is paved in long concrete planks that taper at their ends, allowing plants to pop themselves up in the gaps or spill onto the surface, as if they are angling to envelop the whole structure once again. The landscape renews itself every couple of blocks, woodlands become meadows, become grasslands, become woodlands again. "Peel up" benches appear along the fringes of the concrete trail every so often to provide rest stops on the hiker's journey. There are other ample opportunities to stop and observe along the way, whether that observation is done looking over spurs of planted — this walk is not meant to be a brisk jaunt up to Midtown, but rather a leisurely promenade. As Kenneth Helphand describes in the park's field guide, the High Line is "an atavism of the traditional [eighteenth and nineteenth century]

\footnotetext{
${ }^{122}$ Phil Birge-Liberman, "The Urban Sustainability Fix and the Rise of the Conservancy Park," in Deconstructing the High Line: Postindustrial Urbanism and the Rise of the Elevated Park, Christoph Lindner and Brian Rosa, eds. (New Brunswick: Rutgers University Press, 2017) 135.
} 
promenade, it is a place to see and be seen, and it has developed its own codified and ritualized behaviours." ${ }^{223}$ Along the trail, visitors can visually explore the city that envelops them.

Reminders of the past rail platform are visible where original tracks poke out from the ground terrain; spur overlooks that fork off towards the walls of different buildings now form field and meadow spaces inaccessible from the trail; sunken theatre seating in front of large windows frame a cinematic gaze north up Tenth Avenue; and a curated exhibition of contemporary art pieces dotted along the length of the park. In this space, digital photography is the new method of seeing and being seen, as the park provides infinite opportunities to photograph nature, culture, the city, or yourself.

The architecture of the park is informed by the history of the High Line as a functional rail line. This forms the structure that continually reveals its position as a giant cultural ruin like the ones preserved in Central Park and national parks. Coupled with the planting design, the architectural design creates a tightly controlled environment that reinforces the "ceremonial leisure time" of visiting a museum that the park purportedly aims to deconstruct. ${ }^{124}$ As James Corner Field Operations landscape architect Lisa Switkin describes, "We scripted the experiences we wanted along the line - areas of transition, places to pause and gather, or intimate alcoves." ${ }^{\prime 25}$ When describing the space, park literature uses language that reminds the reader of

\footnotetext{
${ }^{123}$ Kenneth Helphand, "A New Eye Level," in Printed Matter, Inc., and Friends of the High Line Inc. A Field Guide and Handbook of Thought, Musings, Observations, Case Studies, and Histories (Alternative, Conventional \& Otherwise) on the Elevated Structure Formerly and Now Known as the High Line of the Borough of Manhattan for Flâneurs, Cosmopolitans \& Bon Vivants (Minneapolis: Shapco Printing, 2017) 37.

${ }^{124}$ Melanie Kress, "Post No Bills: Illuminating the Art of Advertising," in High Art: Public Art on the High Line, Cecilia Alemani, ed. (New York: Skira Rizzoli, 2015) 125.

${ }^{125}$ James Corner Field Operations landscape architect Lisa Switkin quoted in Piet Oudolf, Gardens of the High Line: Elevating the Nature of Modern Landscapes (Portland: Timber Press, 2017) 92.
} 
its environmental sustainability potential. For example, in publications written by High Line employees, writers claim ownership over terms like agritecture to "stress how crucial the particular marriage of urban and natural environment is for the project." ${ }^{\prime 26}$ The High Line website also has a page dedicated to sustainability practices in the park, addressing concerns about water use, local climatic conditions and plant suitability, composting, pest management, cleaning and debris management. A commitment to sustainable practice states, "Equally important to the High Line's design is the way in which it is maintained and operated on an ongoing basis. In all of our operations, we strive towards sustainability with the same level of care that went into the park's design." ${ }^{127}$ However, at the time of writing, the ecological benefits of the park's reportedly sustainable design are still contested. To its critics, the High Line seems to follow the appearance-centred approach to management akin to that of the national parks. As the park continues to grow and develop, its potential to make a positive impact on local biodiversity and develop a truly sustainable park that requires few additional resources — natural or human - for its successful management remains to be seen.

Where Baker misses the mark in his critique of the park as "ornamental wilderness" is a lack of consideration for the park as a habitat. A 2010 study of the park showed that less animals were living on the High Line after it opened than when it was an abandoned lot. However, in 2017 it was stated that designing and building out the garden has brought more animals to live in

\footnotetext{
${ }^{126}$ Johanna Burton, "A Bend in the Road: Public Art After the High Line," in High Art: Public Art on the High Line, Cecilia Alemani, ed. (New York: Skira Rizzoli, 2015) 21. Footnote 10; Hal Foster, The Art-Architecture Complex (London: Verso, 2011) 103. Unfortunately, the design team was not actually the first to coin this word. The term agritecture was in fact previously used to describe a French eighteenth century school of architecture led by François Cointeraux, see: Paula Lee, "François Cointeraux and the School of "Agritecture" in Eighteenth-Century France," Journal of Architectural Education (1984-) 60, no. 4 (2007): 39-46.

127 "High Line Sustainable Practices," Friends of the High Line, https://www.thehighline.org/about/sustainable-practices.
} 
the park than were there while it was wild. ${ }^{128}$ Habitat space is intentionally created through the choice of plants that provide structure and food sources, most often to support birds. The plant-based habitat above the structure isn't the only approach to habitat construction the park has taken. The idea of the park actively fostering a habitat for animals has also been explored through past art projects such as Sara Sze's Still Life with Landscape (Model for a Habitat), installed in the park from June 2011 to June 2012 between the Chelsea Grasslands and the Chelsea Thicket gardens. This forced perspective architectural network provided habitats, baths, and feeding spots to local birds and butterflies. Sze recounts, “Once the work was installed, the birds flocked to it and regularly and made it their home, rest stop, and feeding ground.... Perhaps even more interesting to observe was the behaviour of people, who tended to the work throughout its time on the High Line, leaving birdseed, water, fruit, bread, and bagels. They posted thousands of photographs online of the sculpture and the birds that inhabited it.... The frequency of the postings suggested that the human observers had never before seen a bird in New York City." 129

\footnotetext{
128 "Elevating the Nature of Modern Landscapes," public lecture, Nov 6, 2017.

${ }^{129}$ Cecilia Alemani, ed., High Art: Public Art on the High Line (New York: Skira Rizzoli, 2015), 106.
} 


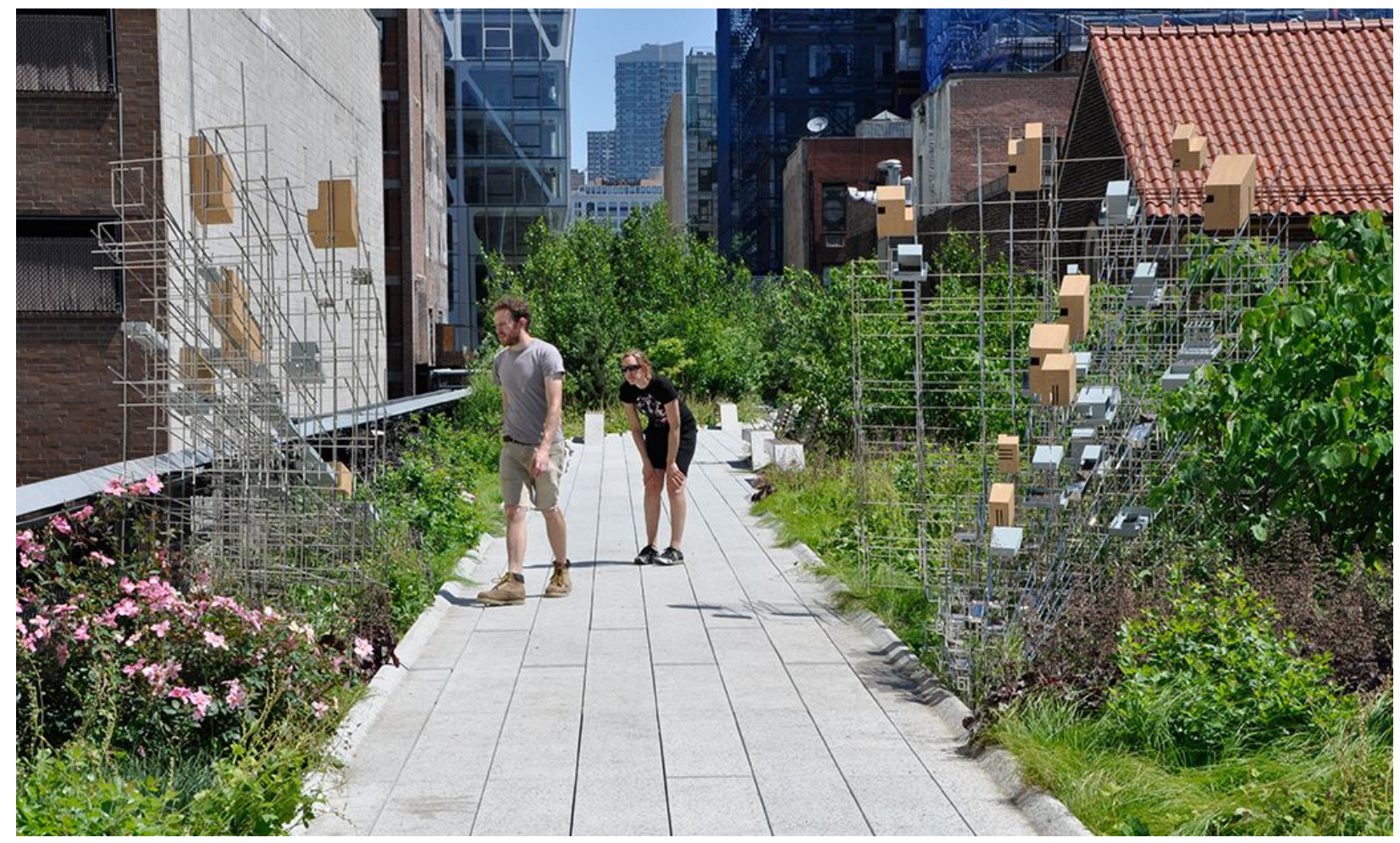

Figure 7. Installation view of Sarah Sze, Still Life with Landscape (Model for a Habitat). 2011. Photograph by Sarah Sze. High Line Art.

The planting design of the park also serves as natural architecture that supports the display of art objects and guides the visual exploration of the park in a way that resembles the rituals of seeing promoted by both Central Park and the national parks. It attempts to promote the idea of "greening" post industrial urban spaces as an environmentally sustainable method of revitalization for both the biodiversity and economy of a landscape. Contributing to this idea of revitalization, the park avoids and attempts to dismantle the presupposition that native plant species are more beneficial to an ecosystem and mixing native and non-native varieties through 
its diverse array of species present in the park. ${ }^{130}$ This practice is promoted through its commitment to a "dynamic" approach to maintaining the garden that incorporates a plant selection based on environmental suitability and changes over time as the climate conditions change. While the design attempts to give the impression of wild plantings, the entire top surface of the rail line was removed, including its diverse flora, in order to install the architectural framework. Planting designer Piet Oudolf then designed a plant mix that included many of the species that were present before the reconstruction along with new species, chosen for both functional and ornamental purposes. ${ }^{131}$ The real estate development that continues to spring up around the High Line means that the plant population must continue to change in response to an increase in shade and other environmental changes that the surrounding high rise structures bring. At a recent lecture it was revealed by Oudolf that planting in the park was based on this progression, and the species planted were chosen with their succession in mind. ${ }^{132}$ Taking this into account, is thus too early to tell whether or not the "ornamental" High Line has successfuly melded form and function until it is a mature environment.

\section{National parks and popular conservation}

In a similar trajectory, the national parks have moved towards becoming sites that combine both scenic beauty and biotically productive environments. Post-WWII, national parks were still primarily understood as "pleasuring grounds," spaces where tourists could get away from industrialized urban centres and out into nature to partake in recreational activities. These

\footnotetext{
${ }^{130}$ Jennifer Foster and L. Anders Sandberg, "Friends or foe? Invasive species and public green space in Toronto," Geographical Review, vol. 94, no. 2 (April 2004) 178-198.

${ }^{131}$ Oudolf, Landscapes.

132 "Elevating the Nature of Modern Landscapes," public lecture, Nov 6, 2017.
} 
tourist sites played a key role in the American national identity. Then-director Newton B. Drury wrote in Our Country's National Parks (1950) “it is necessary that all our citizens, but particularly our young people, know and understand then; that they visualize the power of their scenic beauty and their historic meaning; and understand the need to maintain their integrity." This book and similar publications published in support of the parks, "are a stimulant to patriotism and to constant vigilance against destruction of the Nation's cultural values."133 An increase in this type of popular tourism advertising and publications in the postwar years across the United States led to a renewed interest in the country's natural wonders within the national parks. In response to an anticipated surge in visitor numbers, the National Parks Service implemented a developmental program in 1955 by the name of Mission 66 to establish infrastructure within the parks that would highlight parks as desirable car destinations, right on the heels of construction of the Interstate Highway System. Following the war the parks were in a sorry state, having been resource-strapped for many years; this condition would likely not improve by increased foot traffic on the already overloaded infrastructure within park land. Instead of limiting access to the parks, the Eisenhower Administration ordered the construction or expansion of road systems, visitors centers, and overnight accommodations. This served a hypothetical dual purpose of both regulating the impact and movement of visitors by controlling where they could travel within the parks, and in turn protect land that needed preservation. ${ }^{134}$ Director at the time, Conrad L. Wirth, was planning for a bright future following this

\footnotetext{
${ }^{133}$ Irving Robert Melbo, Our Country's National Parks (New York: The Bobbs-Merrill Company, Inc., 1950) viii.

${ }^{134}$ Peter Peters, "Roadside Wilderness: U.S. National Park Design in the 1950s and 1960s," in Patin, Thomas, Observation Points: The Visual Poetics of National Parks (Minneapolis: University of Minnesota Press, 2012), pp.
} 
"renaissance for the Park Service" in anticipation of over 80 million visitors travelling by road by the year $1966 .{ }^{135}$

Unfortunately, Wirth's entrepreneurial approach to parks management was what Richard West Sellers calls "the antithesis of the scientific approach to park management," and came with its own sacrifices. ${ }^{136}$ After World War II, biology programs in the parks became nearly nonexistent. Scientists' roles were reorganized under the supervision of park rangers or cut out entirely, leaving the parks to seek out contractors on a strained budget via research universities that capitalized on the work of graduate students. This time period led to a decline in science-based park management, "with only two biologists in research and policy, that aspect of the biology programs remained virtually powerless in the surge of Mission 66 activity." ${ }^{137}$ Included in these biology programs were systems of observation that led to informed conservation and land preservation efforts. Wirth believed in the practicality and potential economic viability of the American public to the detriment of producing decades worth of valuable research, especially leading into a time of growing environmental concern.

However, park visitors seemed to pay little attention to the parks themselves with a scientific or environmental rigour and their status as "pleasuring grounds" for the public persisted well into mid century. As Alfred Runte notes, "The annual pilgrimage of three million visitors to Yosemite National Park, for example, does not result from any preoccupation with sugar pines and peregrine falcons; Yosemite's cliffs and waterfalls are the premier attractions." ${ }^{" 138}$

\footnotetext{
${ }^{135}$ M. Guy Bishop, "Mission 66 in the National Parks of Southern California and the Southwest," Southern California Quarterly, vol. 80, no. 3 (Fall 1998), 293-294.

${ }^{136}$ Sellers, Preserving Nature, 173.

137 Sellers, Preserving Nature, 173.

${ }^{138}$ Alfred Runte, "The National Parks in Idealism and Reality," Montana: The Magazine of Western History, Vol. 38, No. 3 (Summer, 1988), 75.
} 
Instead, what drove families to the parks they visited was a public statement of social status and national identity through the exploration and admiration of America's great landscapes. This aesthetic mode of appreciation for their environment stems from nineteenth century intellectuals who asserted that the distinctiveness of national landscapes was proof that the United States was as civilized and powerful as the European nations who fell from power during the war. ${ }^{139}$ "As sanctioned, sacred, and often strategic public places," Lynn Ross-Bryant argues that the function of the parks extends past their preservation of pristine wilderness, "These forests, lakes, deserts, canyons, and glaciers are often displayed as evidence of America's maturity as a nation—as one of democracy's finest achievements - in ways that make particular claims on civic pride and citizenship" 140 essential to crafting the image of the powerful and proud American democracy. As Mission 66 neared completion, more and more visitors were flooding into the parks for recreational automobile-based tourism, and conservation was at an all-time low. Ushering in what Sellers calls "a new era, in which park management would be judged far more on ecological criteria." Yet this era began at the height of national park development under Mission 66 and would confront a half-century of Park Service tradition emphasizing recreational tourism." $" 141$

After the Mission 66 infrastructure boom, National Parks in the 1960s underwent drastic changes in renewed support of providing public infrastructure largely due to the 1963 report, "Wildlife Management in the National Parks," written by Aldo Leopold, author of The Sand County Almanac, that expressed an ecologically-minded ethos echoed from the emerging

\footnotetext{
${ }^{139}$ Runte, "Parks in Idealism and Reality," 75.

${ }^{140}$ Lynn Ross-Bryant, "Sacred Sites: Nature and Nation in the U.S. National Parks," in Religion and American Culture: A Journal of Interpretation, vol. 15, no. 1 (Winter 2005), 31.

${ }^{141}$ Sellers, Preserving Nature, 203.
} 
modern conservation movement. Maintaining the image of the pristine wilderness was still a key element as what became known as The Leopold Report stated that every national park "should represent a vignette of primitive America ... Yet if the goal cannot be fully achieved it can be approached. A reasonable illusion of primitive America could be recreated, using the utmost in skill, judgment and ecologic sensitivity." ${ }^{142}$

By 1972, the NPS incorporated an "environmental ethic." Writing in The National Park Service, NPS Director George B. Hartzog, Jr. declares, "the parks are not perfect sanctuaries, isolated from the ecological dangers which threaten other localities. The pesticide residues that drain from Florida agricultural lands pass into the water system of Everglades National Park, where they menace the delicately balanced chain of live upon which all plant and wildlife in the park depends. The national parks can survive only if the quest for a quality environment is successful." And as the parks had not yet attained Hartzog's vision of the organization, "Recognizing that the national parklands are superlative examples of the nation's natural, historic, and cultural resources, we are seeking a way to use these living standards of excellence in the national search for an environmental ethic." ${ }^{143}$

\section{Conclusion}

As a space of High Line marries the natural with the cultural, steeped in the traditions of the pastoral landscape as an antidote to the wilderness from the nineteenth century but is infused with an environmentally minded consciousness. The cultural status of the park can never be

\footnotetext{
${ }^{142}$ A.S. Leopold, S.A. Cain, C.M. Cottam, I.N. Gabrielson, T.L. Kimball, "Wildlife Management in the National Parks," in America's National Park System: The Critical Documents, ed. Lary M. Dilsaver (Lanham: Rowman and Littlefield, 1994), 239-240.

${ }^{143}$ William C. Everhart, The National Park Service (New York: Praeger Publishers, 1972) vi-vii.
} 
separated from its nature. In this case, the park sits atop the cultural relic of its own historic past, and has embedded the practice of displaying art as a central function of its activities to promote the coexistence between humans and nature. Further, the art program plays a role in continuing to reimagine the park as a habitat through experimental installations, asserting that humans can be positive contributors in environmental health. Therefore, the "version" of nature that the High Line seeks to communicate to its visitors sits in opposition to the Hall of North American Mammals in that this particular wilderness, along with human activity, has a place in the hyperlocal urban environment. Both of the case studies above still display hegemonic ideals of nature or, the natural, with the AMNH's Hall of North American Mammals embodying the ideal of uninhabitable wilderness and High Line as an entwined urban garden. Like museums, parks are entrenched in ritualised experiences of seeing, which poses many questions moving forward. What can museums learn from the design of parks as spaces that are assumed to be "less ceremonial?" Is the park a less socially stratified space? Can an approach that takes inspiration from the design of a park be more accessible than one that takes inspiration from a cathedral? The conflict I have discussed thus far illustrates the constant struggle between humans and the rest of the environment: how do you balance the preservation of objects and landscapes in a way that maintains their integrity in an era when collections and park spaces aim to be for the benefit of the public? 


\section{The Designed Environment}

"Since the invention of the first stone tool, humanity has pounded the wild into a shape that fits its needs. ... Coexisting with nature has always meant taming it - consuming it. As the human population jumped into the billions the rise of human selection as the dominant evolutionary force was inevitable, and so was the end of the wild."

— Stephen M. Meyer

Authenticity through art and science

Through the display of the Hall of North American Mammals, the AMNH creates a culturally relevant scientific experience which is essentially a presentation of art that is explained through the lens of science. The 2012 hall update is an attempt to stay current with scientific research, though it's not a seamless execution. Authenticity is achieved by creating exacting replicas of real spaces that exist outside of the museum using a process that mimics methods of scientific research on an expedition. They are preserved much like historical monuments within the national parks themselves, suspended frozen at a specific point of growth or decay at a specific point in time. Authenticity in the AMNH is the opposite of the High Line: the process of decay is actively reversed through the preservation of the displays themselves which brings the plant and animal specimens back to a state of looking brand-new and immortalizes the landscapes as they were at a specific time in the past, not as they could possibly have changed today.

To counterpoint, the High line is a site of art and culture and that has inspired by popular scientific practice and uses terms that have permeated public thought to associate itself with them. As James Corner's design approach is lodged in an ethos that incorporates ecological ideals but no actual scientific practice and is instead cultural reflection of the values science has 
given us. ${ }^{144}$ Additionally, authenticity on the High Line is achieved by creating a palimpsest of decay: the plant life lives on top of architectural elements that remind visitors of its history as a functional rail line, which live on top of the original structure.

Both the Hall of North American Mammals and the High Line rely on a visual experience. Environmental philosopher Ronald Hepburn writes that nature is frameless while art is always framed, by a literal frame or by the environment it is presented in which connotes that it is an art object (for example, the object exists in a gallery or museum or is displayed with a label). At AMNH they have turned nature into an art object; adding literal frames and creating an environment that encourages the interpretation that the landscape represented within the Hall of North American Mammals are art, or at the very least, art-like. This aligns with the Romantic idea that nature is the "paradigm of aesthetic experience and judgement" but is expressed through the later practice of seeing this paradigm within art that emerged through the nineteenth century. ${ }^{145}$ The High Line has also crafted an experience reliant on the frame. It has been designed to use the forms created by plants and architectural elements to create frames around art objects placed inside the park, or literally framing images in front of theatre seating looking out to the street. This juxtaposition between art installations and literally framing the city as art infuses artistic qualities back into the surrounding urban environment through an aesthetic appreciation which encourages visitors to value the urban environment as they do the 'natural environment' in their immediate surroundings. According to Hepburn, a lack of obvious framing can "[make] room for perceptual surprises and a sense of adventurous openness, and challenges

\footnotetext{
${ }^{144}$ Alan Smart, "Loving the High Line: Infrastructure, Architecture, and the Politics of Space in the Mediated City," in Christoph Lindner and Brian Rosa, eds., Deconstructing the High Line: Postindustrial Urbanism and the Rise of the Elevated Park (New Brunswick: Rutgers University Press, 2017) 54.

${ }^{145}$ Martin Drenthen and Jozef Keulartz, eds. Environmental Aesthetics: Crossing Divides and Breaking Ground (New York: Fordham University Press, 2014) 1.
} 
the appreciator of a natural environment to come up with his or her own "framing." ${ }^{, 146}$ Further, Hepburn argues that appreciating nature as art is a dangerous conflation, and that doing so will negatively affect environmental protections because "a sound natural aesthetics is crucial to sound conservation policy and management," as opposed to an understanding of aesthetic experience rooted in artistic traditions of appreciation. ${ }^{147}$

\section{Audience and access}

Both spaces at their inception aimed to serve local audiences: the AMNH brought remote wilderness to the residents of New York, while the High Line was originally intended to be a public amenity for the Chelsea neighbourhood residents. Originally, the construction of the Hall of North American Mammals was a Grand Tour of the American West and North for urban-dwelling citizens to partake in the culturally-fulfilling experience of virtual travel if they could not themselves, or to inspire their trips around the country in the Mission 66 national parks boom in the postwar years. On a smaller scale, the High Line began as a community project for its residents to bring safe and usable green space to the neighbourhood, yet quickly became a luxury tourist attraction and driver of gentrification. Both have expanded as global icons of the

local, attracting large tourist audiences, the High Line ostensibly at a much faster accelerated rate than the AMNH. Today, the AMNH sees more international, first time visitors through its doors on a day-to-day basis. Programming at the museum rarely, if ever, focuses on topics involving the Hall of North American Mammals and instead features many topics in contemporary science.

\footnotetext{
${ }^{146}$ Drenthen and Keulartz, Environmental Aesthetics, 3.

${ }^{147}$ Drenthen and Keulartz, Environmental Aesthetics, 4.
} 
Likewise, the High Line approaches local engagement through programming opportunities. Additionally, the vast majority of its visitors are non-local tourists.

Tied in to the question of what audiences each site serves is the issue of equitable access, where both not only reinforce an environmental aesthetic that is anthropocentric in nature, but also create a literal environment of the cultural elite. In the past the prominent ties that museums continue to have to elite donors, the museum is presenting an elite, sanitized, perspective through the dioramas of the Hall of North American Mammals. The High Line participates in the same presentation through the redevelopment of the rail structure into a park. Its existence has 'weeded out' people deemed unwelcome in the neighbourhood: people who are lower class, homeless, or drug users, for example. ${ }^{148,149}$ Ultimately, upholding this wilderness ideal of nature and the spaces created inspired by it—such as those discussed at the AMNH and the High Line - doesn't allow for intersection and reinforces these inequities.

\section{The problem with wilderness}

These problems of access inherent to idealized visions of nature can be traced back to a desire to preserve a mythical pristine wilderness. As an understanding of ecological relationships rose to popular prominence in the twentieth century, the question of how to ethically restore, heal, and manage a damaged environment prompted intense debate. The scholarly writing of political scientist Stephen M. Meyer, environmental historian William Cronon, and

\footnotetext{
${ }^{148}$ Jennifer Foster, "Off track, in nature: constructing ecology on old rail lines in Paris and New York," in Nature+ Culture vol. 5, no. 3 (2010) 316.

${ }^{149}$ Darren J. Patrick, "Of Success and Succession: A Queer Urban Ecology of the High Line," in Deconstructing the High Line: Postindustrial Urbanism and the Rise of the Elevated Park, Christoph Lindner and Brian Rosa, eds. (New Brunswick: Rutgers University Press, 2017) 141-168.
} 
environmental philosopher Ramachandra Guha present a spectrum of positions on the matter and serve to help elucidate the problems of our current methods of environmental stewardship.

Meyer argues the American "sense of the wild" can be best encapsulated in the following passage from the U.S Wilderness Act of 1964, defining the term wilderness as

an area where the earth and its community of life are untrammeled by man, where man himself is a visitor who does not remain ... retaining its primeval character and influence, without permanent improvements or human habitation, which is protected and managed so as to preserve its natural conditions and which generally appears to have been affected primarily by the forces of nature, with the imprint of man's work substantially unnoticeable. ${ }^{150}$

For Meyer, this statement reveals the irony that "anthropogenic transformation of the biosphere springs as much from our deliberate efforts to protect and manage the life around us as from our wanton disregard for the natural environment." 151 He criticizes our current methods of biodiversity preservation that include laws and regulations, preserved land, and programs to foster sustainable development as "powerful engines of human selection, tweaking (for our pleasure) but not fundamentally altering the outcome: massive species loss with the attendant disappearance of the wild." ${ }^{152}$ Yet, he later states, "The notion that we should simply let nature take its course is, in a world so thoroughly dominated by humanity, as dangerous as it is self-contradictory." "153 This statement reveals the paradox of both our construction of nature and the ways the conservation and environmental movements have sought to protect it: the "wild" and by extension nature itself is not a self-healing entity that will rebound in biotic health by the removal of human activity. It is human activity that is required not only for preserving the

\footnotetext{
${ }^{150}$ U.S. Code, Title 16, Chapter 23, Section 1131 (c), quoted in Stephen M. Meyer, The End of the Wild (Somerville: Boston Review, 2006) 8.

${ }^{151}$ Stephen M. Meyer, The End of the Wild (Somerville: Boston Review, 2006) 9.

${ }^{152}$ Meyer, End of the Wild, 42.

${ }^{153}$ Meyer, End of the Wild, 73.
} 
appearance of pristine wilderness but also for healing biotically depleted environments. In short, whichever way we decide to act, humans can never be fully extricated from nature.

Part of Meyer's solution to this problem is remedying a dearth of knowledge in environmental fields. He calls for society to "abandon our humanist love affair with the wild" and commit to further research and science communication with a focus on improving our understanding of ecological relationships and processes. ${ }^{154}$ Yet, incongruous with his earlier arguments criticizing land preservation, Meyer suggests that the national park idea of preserving vast tracts of land for the protection of wildlife and more intensive land and species management within these areas.

\section{Similarly to Meyer, William Cronon writes that wilderness as a 'fundamental tenet' of}

the American environmental movement is damaging to our environmental ethics and ignores the fact that nature that is not wild. Instead, Cronon suggests "wildness" as a guiding principle in the establishment of environmental ethics.

[W] e need to embrace the full continuum of a natural landscape that is also cultural, in which the city, the suburb, the pastoral, and the wild each has its proper place, which we permit ourselves to celebrate without needlessly denigrating the others. We need to honor the Other within and the Other next door as much as we do the exotic Other that lives far away-a lesson that applies as much to people as it does to (other) natural things. In particular, we need to discover a common middle ground in which all of these things, from the city to the wilderness, can somehow be encompassed in the word 'home.' 155

Cronon advocates for wildness as opposed to wilderness, rethinking the mundane local environment that was previously considered to be 'unnatural' and not wild by giving consideration to the autonomy of other things - essentially everything that isn't human.

\footnotetext{
${ }^{154}$ Meyer, End of the Wild, 79.

${ }^{155}$ William Cronon, "The Trouble with Wilderness: Or, Getting Back to the Wrong Nature," in Environmental History, vol. 1, no. 1 (Jan 1996) 24.
} 
"Learning to honor the wild" through acknowledgement of this other autonomy also "means striving for critical self-consciousness in all of our actions." ${ }^{156}$ Cronon also envisions the environment around us as nature that can be used and re-used through responsible management of its resources. "If wildness can stop being (just) out there and start being (also) in here, if it can start being as humane as it is natural, then perhaps we can get on with the unending task of struggling to live rightly in the world-not just in the garden, not just in the wilderness, but in the home that encompasses them both." ${ }^{157}$ For Cronon, appreciation of the local "wildness" is critical in reframing our relationship to nature, yet still places humans in a position where all of our needs can and should be met.

Replying to Arne Naess's theory of deep ecology, Ramachandra Guha provides a salient critique to both deep ecology and the flawed nature of the above arguments by Meyer and Cronon. In simplified terms, deep ecology argues that a shift from an anthropocentric to biocentric value system is necessary to remedy environmental destruction. What Guha points out is that this value system functions within the flawed idea that preserving pristine wilderness is the ideal solution to environmental problems. He argues that, although originally ideated by the Norwegian Naess, the idea of deep ecology took hold in America in the midst of the environmental movement and at best is a superficial belief system that cannot be applied to other cultures or geographic locations successfully, stating that "the social consequences of putting deep ecology into practice on a worldwide basis ... are very grave indeed." ${ }^{158}$ The downfall of deep ecology for Guha is that by migrating from the academic field of environmental philosophy

\footnotetext{
${ }^{156}$ Cronon, "The Trouble with Wilderness," 24-25.

${ }^{157}$ Cronon, "The Trouble with Wilderness," 25.

${ }^{158}$ Ramachandra Guha, "Radical American Environmentalism and Wilderness Preservation," in Philosophical Dialogues: Arne Naess and the Progress of Eco-Philosophy, Nina Witoszek and Andrew Brennan, eds. (1999): 315.
} 
into the mainstream environmental movement "truly radical policy proposals" have been put forward by environmentalists adhering to this perspective that elevates the status of pristine wilderness as the apex of nature. Prominent figures in the environmentalism field consequently have suggested "a 90 percent reduction in human populations to allow a restoration of pristine environments, while others have argued forcefully that a large portion of the globe must be immediately cordoned off from human beings." 159 Though Guha welcomes a shift to a biocentric perspective, is becomes "unacceptable" when this strategy begins to marginalize vulnerable human populations through displacement in favour of preserved land. He asserts that the national park idea - preserving large areas of wilderness and barring humans from settling on them is not only dangerous but also ineffective when applied to other parts of the world. Commenting on efforts to establish wilderness areas in areas of the developing world, Guha points out the damaging effects of such actions:

In no case have the needs of the local population been taken into account [in Indian preservation projects such as Project Tiger], and as in many parts of Africa, the designated wildlands are managed primarily for the benefit of rich tourists. Until very recently, wildlands preservation has been identified with environmentalism by the state and the conservation elite; in consequence environmental problems that impinge far more directly on the lives of the poor - e.g., fuel, fodder, water shortages, soil erosion, and air and water pollution — have not adequately addressed..$^{160}$

Therefore, for Guha, the "frankly imperialist manifesto" found within the theory of deep ecology allows for the justification of a singular, deeply flawed approach to conservation through the establishment of larger and larger wilderness areas. It "provides an impetus to the imperialist yearning of Western biologists and their financial sponsors, organizations such as WWF and IUCN. The wholesale transfer of a movement culturally rooted in American conservation history

\footnotetext{
${ }^{159}$ Guha, "Radical American Environmentalism," 315.
}

${ }^{160}$ Guha, "Radical American Environmentalism," 316. 
can only result in the social uprooting of human populations in other parts of the globe."161 Further, Guha points out that the mainstream environmental movement continues to view wilderness areas as "a temporary antidote to modern civilization," further popularizing land that supports the public as an amenity of modern life that improves the standard of living rather than the radically biotically productive space deep ecologists want them to be. ${ }^{162}$ Thus, for Guha, the theory of deep ecology exists within a consumer society without being critical of the social and political conditions which allow it to exist without seriously challenging any norms. "In its celebration of American wilderness, it also displays an uncomfortable convergence with the prevailing climate of nationalism" produced and proliferated through the American national park idea. $^{163}$

Guha's arguments reveal the fatal flaw in upholding the pristine wilderness ideal through the establishment of the national park system and beyond through its global proliferation. What Guha fails to address is that the national park idea was not even socially equitable in its establishment in the nineteenth century. In the same way establishing wilderness areas displaces the global poor, the early national parks evicted Native Americans from land they had been living on for thousands of years. Through the case studies and their problems discussed above, traditional museological institutions such as the American Museum of Natural History are clearly implicated in promoting the ideal of pristine wilderness that even as a method of conservation that appears to be altruistic and perhaps even biocentric, perpetuates vast social inequalities. By upholding and representing the national parks to a glorious level as done so in the Hall of North American Mammals, or by lobbying for the creation of foreign national parks as Carl Akeley did

\footnotetext{
${ }^{161}$ Guha, "Radical American Environmentalism," 317.

162 Guha, "Radical American Environmentalism," 319.

${ }^{163}$ Guha, "Radical American Environmentalism," 319.
} 
through the creation of the Hall of African Mammals, the museum continues to remain entrenched in its imperialist past. Through the writing of Meyer and Cronon, it is clear that the wilderness ideal is a damaging one, yet Guha addresses that the crux of this damage rests in the displacement of marginalized populations.

\section{Conclusion}

In the case of the Hall of North American Mammals and the High Line park, both sites are promoting an anthropocentric view of nature through the highly designed environments they have constructed. Their clear implications with the cultural elite poses a problem not only of biased production of knowledge but also perpetuates problems of access still inherent to museums. As a more traditional institution, the American Museum of Natural History is less nimble and adaptable to change. The Hall of North American Mammals existing in its originally constructed state continues to glorify the wilderness ideal that has a history dating back to the nineteenth century. The Hudson River school painters like Thomas Cole and Frederic Edwin Church popularized this aesthetic through their work and established hegemonic ways of seeing and interpreting the American wilderness. This appreciation for pristine wilderness as nature was strengthened through the establishment of the national parks as scenic "pleasuring grounds" for public use, and through this process, became cemented in the American imagination. While museum figures like Carl Akeley were strongly opposed to the extensive industrialization happening in the West by the early twentieth century, they sought to remedy it not by changing conditions within urban centres, but by lobbying to support and establish more remote wilderness areas. The Hall of North American Mammals is the result of these lobbying efforts and thus perpetuates this specific type of wilderness appreciation that distinctly separates space that 
humans can inhabit from the space of "nature" to the present day, despite changing attitudes in environmental protection and preservation in the face of swift and widespread environmental damage.

Countering the inhospitable wilderness, the urban garden rose to prominence through the nineteenth century amidst urban development in large cities. One such example is Central Park, which sought to be a place where nature and culture could coexist by way of the pastoral landscape. Central Park established an early precedent for the High Line park to be a similar space. Constructed after the American environmental movement of the 1960's, the High Line incorporates park approaches from both Central Park and the national parks to construct a site that infuses the city with nature as a cultural space that is also a sustainable solution to certain ecological problems present in the urban environment. The park aims to build on the design principles from Central Park by rearranging a traditional loop road in which scenic vignettes unfold through its progression to reveal cultural objects and relics, as if in an outdoor art gallery. The High Line, in contrast, responds to its urban setting by framing art objects as well as the city itself along a linear path surrounded by a mix of plant life that fosters a habitat for birds on the New York Flyway, allowing its visitors to reconsider the city as a place where nature can not only exist, but can thrive and support biotic life. While both sites continue to deal with issues inherent to museums: decisions around how to preserve their cultural materials and why, balancing public access with preservation efforts, and working towards creating equitable access for their visitors, it's possible that, like humans and nature, both sites can coexist as successful places of public education. While the Hall of North American Mammals must remain the same, its preservation can hopefully become a relic of past perspectives on how we change and interact 
with our environment. By nature of existing in the middle of the city, the High Line park is becoming a site that disrupts the idea of pristine wilderness and reframes the city as a place where positive environmental restoration can happen and that it can be done by fostering positive human interactions with flora and fauna. 


\section{Bibliography}

Abt, Jeffrey. "The Origins of the Public Museum." In A Companion to Museum Studies, edited by S. MacDonald, 115-134. Malden: Wiley-Blackwell, 2006.

Cecilia Alemani, ed. High Art: Public Art on the High Line. New York: Skira Rizzoli, 2015.

American Museum of Natural History. General Guide. New York: Man and Nature Publications, 1956.

—. Annual Report. New York: The American Museum of Natural History, 1894.

—. Annual Report. New York: The American Museum of Natural History, 1903.

—. Annual Report. New York: The American Museum of Natural History, 1909.

—. Annual Report. New York: The American Museum of Natural History, 1910.

—. Annual Report. New York: The American Museum of Natural History, 1911.

—. Annual Report. New York: The American Museum of Natural History, 1913.

—. Annual Report. New York: The American Museum of Natural History, 1954.

Anthony, Harold. “A Grand Tour of America.” Natural History, vol. 49 (April 1942): 188-193.

Avery, Kevin J. “The Hudson River School.” Heilbrunn Timeline of Art History (October 2004) http://www.metmuseum.org/toah/hd/hurs/hd_hurs.htm.

—. "Frederic Edwin Church (1826-1900)." Heilbrunn Timeline of Art History (August 2009) http://www.metmuseum.org/toah/hd/chur/hd_chur.htm.

Baker, Tom. "The Garden on the Machine.” In Deconstructing the High Line: Postindustrial Urbanism and the Rise of the Elevated Park, edited by Christoph Lindner and Brian Rosa, 109-124. New Brunswick: Rutgers University Press, 2017.

Berkowitz, Carin and Bernard Lightman, eds. Science museums in Transition: Cultures of Display in Nineteenth-Century Britain and America. Pittsburgh: University of Pittsburgh Press, 2017.

Berry, Wendell. Home Economics. San Francisco: North Point, 1987.

Birge-Liberman, Phil. "The Urban Sustainability Fix and the Rise of the Conservancy Park." In Deconstructing the High Line: Postindustrial Urbanism and the Rise of the Elevated 
Park, edited by Christoph Lindner and Brian Rosa, 125-140. New Brunswick: Rutgers University Press, 2017.

Bishop, M. Guy. "Mission 66 in the National Parks of Southern California and the Southwest." Southern California Quarterly, vol. 80, no. 3 (Fall 1998): 293-294.

Boime, Albert. The Magisterial Gaze. Washington: Smithsonian Institution Press, 1991.

Burton, Johanna. "A Bend in the Road: Public Art After the High Line." In High Art: Public Art on the High Line, edited by Cecilia Alemani, pp-pp. New York: Skira Rizzoli, 2015.

Cameron, Duncan F. "The Museum, a Temple or the Forum." Curator, vol. 14, no. 1 (March 1971): 61-73.

Carr, Gerald L. In Search of the Promised Lands: Paintings by Frederic Edwin Church. New York: Berry-Hill Galleries, Inc., 2000.

Cole, Thomas. "Essay on American Scenery." American Monthly Magazine, vol. 1 (January 1836): $1-12$.

Cronon, William. "The Trouble with Wilderness: Or, Getting Back to the Wrong Nature." Environmental History, vol. 1, no. 1 (Jan 1996): 7-28.

Cusack, Tricia. Riverscapes and National Identities. Syracuse: Syracuse University Press, 2010.

Dallas Museum of Art. "Louis Legrand Noble's After Icebergs with a Painter (1861)." https://collections.dma.org/essay/5ndk60Yx

David, Joshua and Robert Hammond. High Line: The Inside Story of New York's Park in the Sky. New York: Farrar, Straus and Giroux, 2011.

De Forest, Robert W. Report of the Trustees for the Year Ended December 31, 1915. New York: The Metropolitan Museum of Art, 1915.

Drenthen, Martin and Jozef Keulartz, eds. Environmental Aesthetics: Crossing Divides and Breaking Ground. New York: Fordham University Press, 2014.

Duncan, Carol and Alan Wallach. "The Universal Survey Museum." Art History, vol. 3 no. 4 (December 1980): 448-469.

Durand, Asher B. "Letters on Landscape Painting." Letter II. The Crayon, vol. 1 (January 17, 1855): 34-35.

Everhart, William C. The National Park Service. New York: Praeger Publishers, 1972. 
Flad, Harvey K. "The Parlor in the Wilderness: Domesticating an Iconic American Landscape." Geographical Review, vol. 99, no. 3 (July 2009): 356-376.

Foster, Hal. The Art-Architecture Complex. London: Verso, 2011.

Foster, Jennifer and L. Anders Sandberg. "Friends or foe? Invasive species and public green space in Toronto.” Geographical Review, vol. 94, no. 2 (April 2004): 178-198.

Foster, Jennifer. "Off track, in nature: constructing ecology on old rail lines in Paris and New York." Nature + Culture vol. 5, no. 3 (2010): 316.

Friends of the High Line. "High Line Sustainable Practices." https://www.thehighline.org/about/sustainable-practices.

Gopnik, Adam. “A Walk on the High Line.” The New Yorker, May 21, 2001.

Gray, Christopher. "Streetscapes: The West Side Improvement; On the Lower West Side, Fate Of Old Rail Line Is Undecided.” New York Times, January 3, 1988, Late edition.

Griffiths, Alison. Shivers Down Your Spine: Cinema, Museums, and the Immersive View. New York: Columbia University Press, 2008.

Guha, Ramachandra. "Radical American Environmentalism and Wilderness Preservation." In Philosophical Dialogues: Arne Naess and the Progress of Eco-Philosophy, edited by Nina Witoszek and Andrew Brennan, 313-324. New York: Rowman \& Littlefield Publishers, Inc., 1999.

Haraway, Donna. "Teddy Bear Patriarchy: Taxidermy in the Garden of Eden, New York City." Social Text, vol. 11 (1984-1985): 20-64.

Heartney, Eleanor. "Art \& Nature and Technology: Remaking Land and Body.” In Art \& Today, pp-pp. New York: Phaidon Press, 2008.

Helphand, Kenneth. “A New Eye Level.” In Printed Matter, Inc., and Friends of the High Line Inc. A Field Guide and Handbook of Thought, Musings, Observations, Case Studies, and Histories (Alternative, Conventional \& Otherwise) on the Elevated Structure Formerly and Now Known as the High Line of the Borough of Manhattan for Flâneurs, Cosmopolitans \& Bon Vivants, pp-pp. Minneapolis: Shapco Printing, 2017.

Kress, Melanie. "Post No Bills: Illuminating the Art of Advertising." In High Art: Public Art on the High Line, edited by Cecilia Alemani, pp-pp. New York: Skira Rizzoli, 2015.

Leopold, A.S., S.A. Cain, C.M. Cottam, I.N. Gabrielson, and T.L. Kimball. "Wildlife Management in the National Parks." In America's National Park System: The Critical 
Documents, edited by Lary M. Dilsaver, 210-224. Lanham: Rowman and Littlefield, 1994.

Maslow, Abraham H. Religions, Values, and Peak-Experiences. New York: Penguin/Arkana, 1994.

"MAYOR DEDICATES WEST SIDE PROJECT." New York Times, June 29, 1934.

Melbo, Irving Robert. Our Country's National Parks. New York: The Bobbs-Merrill Company, Inc., 1950.

Metropolitan Museum of Art. American Paradise: The World of the Hudson River School. New York: H.N. Abrams, 1987.

Meyer, A. B. "Studies of the museums and kindred institutions of New York City, Albany, Buffalo, and Chicago, with notes on some European institutions." In Report of the United States National Museum for 1903, 311-608. Washington: Government Printing Office, 1905.

Meyer, Stephen M. The End of the Wild. Somerville: Boston Review, 2006.

Miller, Angela L. "The Fate of Wilderness in American Landscape Art: The Dilemma of 'Nature's Nation."' In A Keener Perception: Ecocritical Studies in American Art History, edited by Alan C. Braddock and Christoph Irmscher, 85-109. Tuscaloosa: The University of Alabama Press, 2009.

Mitchell, Timothy. "Frederic Church's 'The Icebergs': Erratic Boulders and Time's Slow Changes." Smithsonian Studies in American Art, vol. 3, no. 4 (Autumn 1989): 2-23.

Novak, Barbara. Nature and Culture. New York: Oxford University Press, 2006.

Olmsted, Frederick Law. "Passages in the Life of an Unpractical Man." In F.L. Olmsted, Landscape into Cityscape: Frederick Law Olmsted's Plans for a Greater New York City, 50-62. Ithaca: Cornell University Press, 1968.

Oudolf, Piet. Gardens of the High Line: Elevating the Nature of Modern Landscapes. Portland: Timber Press, 2017.

Patin, Thomas. "America in Ruins: Parks, Poetics, and Politics." In Observation Points: The Visual Poetics of National Parks, pp-pp. Minneapolis: University of Minnesota Press, 2012.

Patrick, Darren J. "Of Success and Succession: A Queer Urban Ecology of the High Line," in Deconstructing the High Line: Postindustrial Urbanism and the Rise of the Elevated 
Park, edited by Christoph Lindner and Brian Rosa, 141-168. New Brunswick: Rutgers University Press, 2017.

Peters, Peter. "Roadside Wilderness: U.S. National Park Design in the 1950s and 1960s." In Observation Points: The Visual Poetics of National Parks, by Thomas Patin, 55-76. Minneapolis: University of Minnesota Press, 2012.

Pohl, Frances K. Framing America: A Social History of American Art. New York: Thames and Hudson, 2012.

Quinn, Stephen C. Windows on Nature: The Great Habitat Dioramas of the American Museum of Natural History. New York: Harry N. Abrams, 2006.

Raab, Jennifer. Frederic Edwin Church: The Art and Science of Detail. New Haven: Yale University Press, 2015.

Rader, Karen A., and Victoria E.M. Cain. Life on Display: Revolutionizing U.S Museums of Science and Natural History in the Twentieth Century. Chicago: The University of Chicago Press, 2014.

Reiss, Michael J. and Sue Dale Tunnicliffe. "Dioramas as Depictions of Reality and Opportunities for Learning in Biology." Curator: The Museum Journal, vol. 54, no. 4 (2011): 447-459.

Rosenzweig, Roy, and Elizabeth Blackmar. The Park and the People: A History of Central Park. Ithaca: Cornell University Press, 1992.

Ross-Bryant, Lynn. "Sacred Sites: Nature and Nation in the U.S. National Parks." Religion and American Culture: A Journal of Interpretation, vol. 15, no. 1 (Winter 2005): 31-62

Runte, Alfred. "The National Parks in Idealism and Reality." Montana: The Magazine of Western History, vol. 38, no. 3 (Summer, 1988): 75-76.

Sellers, Richard West. Preserving Nature in the National Parks: A History. New Haven: Yale University Press, 2009.

Smart, Alan. "Loving the High Line: Infrastructure, Architecture, and the Politics of Space in the Mediated City," in Deconstructing the High Line: Postindustrial Urbanism and the Rise of the Elevated Park, edited by Christoph Lindner and Brian Rosa, 41-60. New Brunswick: Rutgers University Press, 2017.

Wilton, Andrew and T. J. Barringer. American Sublime: Landscape Painting in the United States, 1820-1880. Princeton: Princeton University Press, 2002. 
Wise, M. Norton and Elaine M. Wise. "Reform in the garden." Endeavour, vol. 26, no. 4 (2002): 154-159.

Yanni, Carla. "Divine Display or Secular Science: Defining Nature at the Natural History Museum in London." Journal of the Society of Architectural Historians, vol. 55, no. 3 (September 1996): 276-299. 